\title{
A systematic review on supplier selection and order allocation problems
}

\author{
Sourour Aouadni ${ }^{1,2} \cdot$ Ismahene Aouadni ${ }^{1,2} \cdot$ Abdelwaheb Rebaï $^{2}$
}

Received: 12 July 2019 / Accepted: 4 November 2019 / Published online: 13 November 2019

(c) The Author(s) 2019

\begin{abstract}
The supplier selection and order allocation are two key strategic decisions in purchasing problem. The review presented in this paper focuses on the supplier selection problems (SSP) and order allocation from year 2000 to 2017 in which a new structure and classification of the existing research streams and the different MCDM methods and mathematical models used for SSP will be presented. The review was examined in three aspects: the summaries of the existing evidence concerning the problems, the identification of gaps in the current research to help determine where further investigation might be needed and positioning new research activities.
\end{abstract}

Keywords Supplier selection · Single sourcing · Order allocation · Optimization · Multi-criteria decision making $\cdot$ Multiple sourcing

\section{Introduction}

The supplier selection problem (SSP) is a procurement decision-making problem that consists of the definition of methods and the models to analyze and measure the performance of a set of suppliers in order to improve customer's competitiveness. This decision is more complex because the diversity of quantitative and qualitative criteria assigns on evaluation and decision-making process. Various decisionmaking techniques have been proposed in the literature to remove this problem, particularly those of multi-criteria analysis which use both quantitative and qualitative data. Additionally, in the function supply, the decision of choosing the best suppliers consists in deciding whether we shall use single- or multiple-sourcing strategies during the acquisition of a given material resource. Also, the supplier selection and order allocations are two key strategic decisions in purchasing problem. Then, these decisions are more complex and

Sourour Aouadni

sourour_aouadni@yahoo.fr

1 College of Business, Department of Business Administration, Bisha University, Bisha, Saudi Arabia

2 Laboratory of Modeling and Optimization for Decisional, Industrial and Logistic Systems, Sfax University, Sfax, Tunisia various techniques have been proposed in the literature to solve these problems.

Several taxonomies and review literature papers devoted to the supplier selection problem such as De Boer et al. (2001); Aissaoui et al. (2007); Ho et al. (2010); Chai et al. (2013); Wetzstein et al. (2016).

In recent year, the number of researcher's work is interesting in supplier selection with order allocation is increased, but a few of systematic reviews consider this issue. For these reasons, our intention is to present a rigorous review of scientific literature, by presenting a classification of these works for a large period (17 years) which was not taken into consideration in the other surveys.

This study proposes a new structure and classification of the existing research streams and the different methods used for SSP and order allocation as well as identifying gaps in the current research and delineating future research avenues with the aim of relating the existing quantitative methods to empirical research.

The main contribution of this paper is to provide a comprehensive literature review of supplier selection with order allocation during the last 17 years, which shows a significant increase in research work published in this field. In this study, we will apply the classification framework developed by Denyer and Tranfield (2009) in order to advance our understanding of the field of supplier selection and order allocation and to facilitate to the researchers to discover 
meaningful information concerning this subject. Also, this new classification seeks to identify any new trends in this field and highlight any gaps that would benefit from future research efforts, including MCDM methods and optimization models. Finally, this survey aims to enhance our ability to discover important knowledge in this large number of literature.

Given this evolving research field, this paper analyzes research in international scientific journals that focus on this field and build a relevant framework for classifying the most papers published since 2000 until to 2017. Consequently, we provided a bibliography of 270 published papers in order to answer the following questions: which journals are mostly touched on this problem? Which multi-criteria decisionmaking methods are frequently applied in the process of supplier selection? Which mathematical models are prevalently used to formulate the supplier selection and order allocation problem? Which techniques are frequently used to solve these models? What are the limitations of these methods and models?

In this paper, we present the most popular methods and models used in these problems. Firstly, we summarize the most characteristics about the supplier selection process and we tried to classify the different multi-criteria decision methods of collecting papers in two categories: single criterion and outranking synthesis approaches. Secondly, we present an extensive review and analysis of the decision models of a multiple-sourcing problem in the supplier selection. Moreover, a classification of mathematical models according to the objective function is a single-objective function or multiple-objective functions. Finally, we tried to analyze the hybrid methods used in supplier selection and order allocation problems.

The remainder of this paper is organized as follows: Section "Research methodology" presents the research methodology used in the topic of supplier selection and order allocation. Section "Analyzing and reporting" concerns about analyzing and reporting. Section "Observations and remarks" presents an observation and discussion about the most prevalently used methods and journals by years.

\section{Research methodology}

In this study, we describe the systematic review for classifying the published papers about 2000 until to 2017 in this topic. Systematic review is defined by Denyer and Tranfield (2009) as "a specific methodology that locates the existing studies, selects and evaluates contributions, analyses and synthesizes data, and reports the evidence in such a way that allows reasonably clear conclusions to be reached about what is and is not known."
The introduction of the use of systematic evaluation processes in particular of systematic literature review will help to obtain an objective summary of research evidence concerning this topic by producing better-quality reviews and evaluations.

The systematic reviews review the primary data which can be either quantitative or qualitative and synthesize the findings of previous research investigating the same or similar questions.

The systematic reviews use a systematic approach to search, select and appraise the produced evidence, and they employ explicit rigorous and accountable methods to inform new research questions.

In this paper, we based on the five-step procedure proposed by Denyer and Tranfield (2009) describe the systematic review:

Step 1 Formulate the questions: we follow the CIMO logic proposed by Denyer et al. (2008) to formulate clear questions whose purpose is to establish the focus of the study and to frame the inclusion criteria. This logic of the CIMO is as follows: "in this class of problematic Contexts, use this Intervention type to invoke these generative Mechanism(s), to deliver these Outcome(s)" (Denyer et al. 2008).

Applying the ICMO logic, we formulate the design proposition to identify the four main elements:

If a buyer aims to take a decision concerning a supplier selection and order allocation problem which characterized by multiple criteria and multiple suppliers (C), it should use a multi-criteria decisionmaking method and the mathematical optimization (I) based on the opinion of one or group decisionmakers in order to rank suppliers according to their importance and the definition of the different objectives and constraints to take the optimal decision of order allocation (M) in order to select the best suppliers and distribute the order quantity between them $(\mathrm{O})$.

Step 2 Locating studies: This step aims to locate, select and appraise the relevant researches as much as possible.

Relevant papers were targeted using electronic academic databases including science direct, IEEE Xplore, Springer link Journals, Emerald, Taylor and Francis and so on. These papers are searched in the search databases using the following keywords: "vendor selection," "supplier selection," "supplier evaluation," multi-criteria supplier selection "order allocation," "order lot-sizing," "optimization supplier selection" and covering major journals in the fields of "Management Science," "Operations Research," "Purchasing 
Table 1 Distribution of articles in major journals in the period 2000-2017

\begin{tabular}{lcc}
\hline Journal & Total & Percentage \% \\
\hline Expert Systems with Applications & 64 & 23.70 \\
International Journal of Production Economics & 35 & 12.96 \\
European Journal of Operational Research & 26 & 9.62 \\
Applied Mathematical Modelling & 15 & 5.55 \\
Computers and Industrial Engineering & 15 & 5.55 \\
International Journal of Production Research & 12 & 4.44 \\
Omega: The International Journal of Management Science & 9 & 3.33 \\
Others & 94 & 34.81 \\
\hline
\end{tabular}

Management" and "supply chain management and logistics" from 2000 to 2017 (up to September 2017).

Step 3 Study selection and evaluation: this step defines the inclusion and exclusion criteria to focus on relevant papers.

This survey was taken to identify papers that had been published in high-ranking journals in order to increase the validity of this systematic literature review.

To ensure the relevance of the papers, we consider only English papers. We read as first research 400 abstracts on this topic. We extended the master's thesis, doctoral dissertation, textbooks and unpublished articles and nonEnglish papers. We ended up with 300 papers in total.

An article is included in this survey if it is thoroughly based on pre-selection methods, MCDM methods, order allocation models and methods and hybrid methods of the supplier selection problem. As a result, 270 articles are reviewed attempting to be as exhaustive as possible. This scope makes to researchers the most valuable information and an extensive search concerning the supplier selection problem and order allocation. In addition, we excluded researches devoted to green supplier selection and sustainable supplier selection.

Step 4 Analysis and synthesis: in this step, we extract and store the important information about the studied problem from the collection of the most relevant papers.

We used the designed questions proposed in Step 1 to extract the relevant information. The results obtained in this step are the description and the classification of the papers.

Step 5 Reporting and using the results: in this last step, a systematic review should be structured in a similar manner to a report of empirical research which includes an introduction, methodology, findings and conclusion.
The first three steps have been well discussed in research methodology. Now, we focus on analysis and reporting in the following sections.

\section{Analyzing and reporting}

Table 1 presents the distribution of the papers based on the name of journal in which the 270 papers specific to the problem of supplier selection and order allocation. The lapse of time of these papers is between 2000 and 2017 for identifying the trends in the chronological progression of research on problem of supplier selection and order allocation.

Since 2000, the number of publications in the domain of the SSP and order allocation has grown increasingly. Figure 1 shows that the most number of published papers in this domain are in the period 2009-2013, especially in 2011 so that we find 40 published papers and the important method used is the TOPSIS which is a qualitative technique (see Fig. 1).

In addition, the most techniques used in this period for solving SSP are qualitative techniques such as TOPSIS and AHP. Overall, the multi-criteria nature of the supplier selection problem is the main reason that explain the usage of these MCDM approaches.

\section{Problem context-based classification}

In the function supply, the decision of choosing the best suppliers consists in deciding whether we shall use single- or multiple-sourcing strategies during the acquisition of a given material resource.

\section{Supplier selection (single sourcing)}

In this decision, one supplier can satisfy all the buyer's needs and the buyer makes only one decision: which supplier is the best. Gary Dickson in 1966 is the first of the pioneers who became interested in the topic. He defined this problem as follows: «The vendor selection problem is associated with 
Fig. 1 Distibution of papers by year

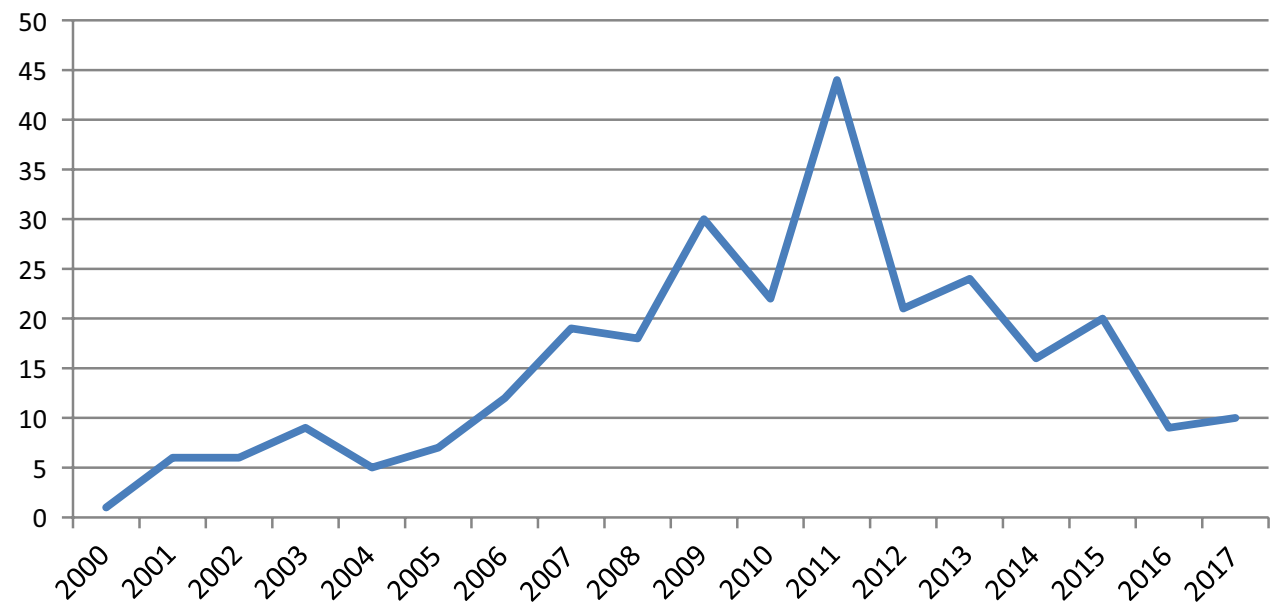

deciding how one vendor should be selected from a number of potential alternatives.» (Dickson 1966).

In this problem, the purchasing department makes the decision about whether one or more suppliers are selected from a number of alternatives and for the completion of an activity or the provision of a product. In the case where several activities are carried out, we talk about the problem of the supplier selection if the activities are treated independently (no synchronization between activities, no precedence constraints).

\section{Order allocation problem (multiple sourcing)}

In purchasing problem, we talk about "order allocation problem" where the activities are subject to precedence constraints.

In multiple sourcing, as no supplier can satisfy all the buyer's requirements, more than one will be selected. In this situation, the buyer purchases the same items from more than one supplier, and the total demand is split among them. The order quantity is split among suppliers for a variety of reasons such as cost, quality and capacity. This decision consists in combining the supplier selection with the order allocation problem. In this decision, more questions arise: What order quantity should be allocated to each supplier? Which order should be assigned to each supplier? And which period, in the planning horizon, should be used?

\section{Methodology-based classification}

\section{Pre-selection of potential suppliers' methods}

The aim of this phase is to reduce the number of suppliers for the final selection using the multi-criteria decision-making method. Therefore, the purpose of this phase is to rule out the inefficient candidates and reduce the set of all the
Table 2 Classification of pre-selection methods

\begin{tabular}{llll}
\hline No. & Criteria & $\begin{array}{l}\text { Number of } \\
\text { articles }\end{array}$ & Percentage \% \\
\hline 1 & Categorical & 1 & 3.84 \\
2 & Linear weighted aver- & 2 & 7.69 \\
& age method & & \\
3 & DEA & 13 & 52 \\
4 & Cluster analysis & 03 & 11.53 \\
5 & CBR & 06 & 23.07 \\
Total & & 25 & \\
\hline
\end{tabular}

suppliers to a small range of acceptable ones. It is a simple step in evaluating suppliers and developing a list of potential key suppliers based on a set of factors, such as experience, financial ability, managerial ability, reputation and work history. In the following paragraphs, we will discuss the supplier pre-qualification approaches, and Table 2 summarizes the using of these methods:

Categorical methods The main papers using the categorical method in the supplier selection problem are those of Khaled et al. (2011).

Linear weighted average method Amid et al. (2006) solved a fuzzy multi-objective linear model supplier selection problem in a supply chain by applying an asymmetric fuzzy-decision-making technique. $\mathrm{Ng}$ (2008) constructed a weighted linear program for the multi-criteria supplier selection problem by using a transformation technique that could solve the problem without applying an optimizer.

Data envelopment analysis (DEA) Liu et al. (2000) proposed a simplified DEA model to evaluate the supplier's performance as the basis of 3 inputs, price index, delivery performance and distance factor, and 2 output criteria which are the supply, variety and quality. Narasimhan et al. (2001) proposed factors to apply the DEA to evaluate the suppliers of a multi-national corporation in the telecommunication 
industry. Talluri and Baker (2002) used the DEA method with two input and four output factors to evaluate the potential stakeholders (suppliers, manufacturers, retailers and distributors). Talluri and Narasimhan (2004) proposed the DEA for an effective supplier sourcing based on the crossefficiencies and statistical methods in clustering the supply base. Garfamy (2006) applied the DEA by focusing on the total cost of ownership (TCO) to measure the overall performances of suppliers. Saen (2006) developed an innovative method based on the DEA model to evaluate the technology suppliers on mainly three factors, in which there is a qualitative factor-amount of know-how transfer. In the research of Seydel (2006), the DEA is used to solve the supplier selection problem. Talluri et al. (2006) proposed a chanceconstrained DEA approach to evaluate the performance of the suppliers taking into consideration the stochastic performance measures. Wu et al. (2007) proposed an augmented imprecise DEA approach for the selection of the suppliers. $\mathrm{Wu}$ and Blackhurst (2009) proposed a methodology called the augmented DEA to evaluate and select the best supplier. This method enhanced the discriminatory power over the basic DEA models to rank the suppliers. Songhori et al. (2011) proposed a structured framework to solve the supplier's selection with order allocation problem for their firm using DEA. Falagario et al. (2012) proposed a tender evaluation method based on the DEA method and related concept of cross-efficiency. Karsak and Dursun (2014) proposed a new fuzzy multi-criteria group decision-making method for supplier selection combined quality function deployment (QFD) and data envelopment analysis (DEA).

Cluster analysis Hong et al. (2005) applied a clustering method to find out the best suppliers on the basis of: preparation, pre-qualification and final selection, so, they could maximize the revenue while satisfying the customer's needs. Bottani and Rizzi (2008) presented a hybrid method using the cluster analysis and the AHP. Ha and Krishnan (2008) introduced a hybrid method which incorporates multiple techniques into the supplier's evaluation process in order to select the most competitive one(s) in the supply chains.

Case-based reasoning method (CBR) Choy and Lee (2002) proposed a generic model of CBR integrating customer relationship management (CRM) and a supply chain management (SCM).The model was applied to a consumer product manufacturing company, which maintained a database of past suppliers and their attributes. Like in the work of Choy and Lee $(2002,2003)$ and Choy et al. (2002), Choy et al. (2003) applied the CBR-based methodology for the supplier selection problem. Humphreys et al. (2007) integrated both the case base reasoning and the decision support components including multi-attribute analysis which presents a framework to measure the supplier's environmental performance.
Table 3 Classification of MCDM methods

\begin{tabular}{lccc}
\hline Abbreviations & $\begin{array}{l}\text { Number of } \\
\text { articles }\end{array}$ & $\begin{array}{l}\text { Local percent- } \\
\text { age } \%\end{array}$ & $\begin{array}{l}\text { Global per- } \\
\text { centage } \%\end{array}$ \\
\hline \multicolumn{2}{l}{$\begin{array}{l}\text { Single-criterion synthesis approach } \\
\text { Number total of papers }=122\end{array}$} & & \\
AHP & 47 & 38.52 & 17.40 \\
ANP & 21 & 17.21 & 7.78 \\
MAUT & 2 & 1.63 & 0.74 \\
SMART & 4 & 3.27 & 1.48 \\
TOPSIS & 26 & 21.31 & 9.62 \\
VIKOR & 7 & 5.73 & 2.59 \\
SIR & 1 & 0.81 & 0.37 \\
BWM & 2 & 1.63 & 0.74 \\
Outranking synthesis & approach & & \\
ELECTRE & 6 & 4.91 & 2.22 \\
PROMETHEE & 6 & 4.91 & 2.22 \\
\hline
\end{tabular}

\section{Multi-criteria decision-making methods}

This phase consists in determining the method for the final selection of suppliers and the allocation of final-order quantities among them. In this step, several methods have been used in the literature to evaluate and select the suppliers and many researches classified these methods in various categories. De Boer et al. (2001) positioned the qualitative methods in step formulation of the problem and criteria but the quantitative methods are involved in the final stages of the qualification and selection of the suppliers. Ho et al. (2010) classified the techniques of the supplier's selection into individual and integrated approaches. Then, Chai et al. (2013) selected and reviewed 123 journal articles, between 2008 and 2012, which were used in the supplier' evaluation and selection. They classified 26 techniques into three categories, namely Multi-criteria decision-making (MCDM) techniques, mathematical programming (MP) techniques and artificial intelligence (AI) techniques.

In this study, we classify the MCDM approaches used to solve the supplier selection problem into two categories such as (1) single-criterion synthesis approach and (2) outranking synthesis approach (see Table 3).

Single-criterion synthesis approach The key multi-criteria decision-making methods within this approach include: MAUT, SMART, UTA, TOPSIS, AHP and GP.

Analytic Hierarchic Process (AHP) Akarte et al. (2001) developed a web-based AHP system to evaluate the casting suppliers on 18 criteria, six objectives and twelve subjective and divided them into four groups. Tam and Tummala (2001) applied the AHP approach to a real case study to examine its feasibility in selecting a vendor for a telecommunication system. Muralidharan et al. (2002) proposed a 
five-step AHP-based model which incorporated nine criteria to select the suppliers. Chan (2003) developed an interactive selection model using the AHP method to facilitate the selection of suppliers. Liu and Hai (2005) used Noguchi's voting and ranking method to solve the supplier selection based on the AHP method. Hou and Su (2007) proposed an AHP-based decision support system to identify the appropriate suppliers of components in a mass customization environment. Chan and Chan (2010) used an AHP method to solve the supplier selection problem in the apparel industry. Peng (2012) used the AHP method to evaluate and select logistics outsourcing service suppliers and applied an actual case. Chen and $\mathrm{Wu}$ (2013) proposed a modified failure mode and effect analysis (MFMEA) method to select new suppliers from the supply chain of risk perspective. Deng et al. (2014) proposed a D-AHP method for the supplier selection problem, which extends the classical analytic hierarchy process (AHP) method, based D numbers, that is a new, effective and feasible representation of uncertain information. Dweiri et al. (2016) proposed a decision support model for supplier selection based on analytic hierarchy process (AHP) using a case of automotive industry in a developing country of Pakistan.

The many papers integrated AHP with other approaches to evaluate the performance of suppliers and select the best supplier are those of: Chen and Huang (2007), Saen (2007b), Sevkli et al. (2007), Ha and Krishnan (2008), Çebi and Bayraktar (2003), Wang et al. (2004, 2005), Yang and Chen (2006), Xia and Wu (2007), Lin et al. (2011), Rezaei and Davoodi (2012), Kar (2015) and Segura and Maroto (2017).

The proposed approaches integrated with fuzzy set in AHP method are: Kahraman et al. (2003), Chan and Kumar (2007), Bottani and Rizzi (2008), Yang et al. (2008), Chan et al. (2008), Lee (2009), Chamodrakas et al. (2010), Sen et al. (2010), Zeydan et al. (2011), Yucenur et al. (2011), Chen and Chao (2012), Shaw et al. (2012), Yu et al. (2012), Rezaei and Ortt (2013), Junior et al. (2014), Rezaei et al. (2014), Ayhan and Kilic (2015), Lee et al. (2015), Beikkhakhian et al. (2015), Bruno et al. (2016), Tavana et al. (2016), Büyüközkan and Göçer (2016, 2017).

Analytic Network process (ANP) Sarkis and Talluri (2002) applied the ANP method to help decision makers select the best supplier by taking into account the organizational factors and strategic performance metrics, which consist of seven evaluating criteria. Bayazit (2006) proposed an ANP method to select the right supplier by identifying ten evaluating criteria that were categorized into supplier's performance and capability clusters. Gencer and Gürpinar (2007) implemented an ANP model for an electronic company to evaluate and select the most appropriate supplier as the basis of various evaluating criteria. Lin et al. (2010) proposed a hybrid MCDM technique to cope with the complex and interactive supplier selection problem in determining the structural relationships and the interrelationships among all the evaluation dimensions. Wan et al. (2017) used ANP and ELECTRE II in interval 2-tuple linguistic environment for solving supplier selection problems with two-level criteria. The authors developed a 2-tuple linguistic ANP (TL-ANP) approach to derive criteria and sub-criteria weights.

The papers using the fuzzy ANP are those of: Lin (2009), Amin and Razmi (2009), Razmi et al. (2009a), Onüt et al. (2009), Yucenur et al. (2011), Xiao et al. (2012) and Lin (2012). The researches combined ANP with other methods such as Demirtas and Üstün (2008, 2009), Ustun and Demirtas (2008), Tseng et al. (2009), Razmi and Rafiei (2010), Lin et al. (2011), Aouadni et al. (2013) and Ghadikolaei and Parkouhi (2017).

Multiple-attribute utility theory (MAUT) There is one research that used this method in SSP, Sanayei et al. (2008) which presented an effective model using both MAUT and LP to solve the supplier selection problem. Segura and Maroto (2017) applied a multiple-criteria supplier segmentation approach based on PROMETHEE and multi-attribute utility theory (MAUT)

Simple Multi-Attribute Rating Technique (SMART) Barla (2003) conducted a five-step approach based on the SMART for the supplier evaluation and selection in a glass manufacturing company. Huang and Keska (2007) presented a comprehensive set of 101 metrics collected from the literature for the supplier selection. Other papers integrated the SMART with other approaches, for example, Seydel (2005) and Chou and Chang (2008).

Technique for Order of Preference by Similarity to Ideal Solution (TOPSIS) Shyur and Shih (2006) present an effective model using both ANP and modified TOPSIS, to accommodate the criteria with interdependencies in supplier selection problem. Junior et al. (2014) presented a comparing study between the fuzzy AHP and the fuzzy TOPSIS methods to solve the problem of supplier selection. Wood (2016) applied fuzzy and intuitionistic fuzzy TOPSIS with flexible entropy weighting to evaluate and select supplier considering criteria relevant to an oil and gas facilities development project. Aouadni et al. (2017) developed the cardinal data TOPSIS method (TOPSIS-CD method) and the meaningful mixed data TOPSIS method (TOPSIS-MMD method) which suggest novel reference points and extend the TOPSIS method to mixed data. These two extended methods applied to a multi-attribute supplier selection problem. Aouadni et al. (2017) developed the cardinal data TOPSIS method (TOPSIS-CD method) and the meaningful mixed data TOPSIS method (TOPSIS-MMD method) which suggest novel reference points and extend the TOPSIS method to mixed data.

The different papers that used the hybrid fuzzy TOPSIS method for the supplier selection problem are those of: Chen et al. (2005, 2006), Boran et al. (2009), Onüt et al. (2009), 
Razmi et al. (2009b), Guneri et al. (2009), Awasthi et al. (2010), Dalalah et al. (2011), Zeydan et al. (2011), Kara (2011), Deng and Chan (2011), Chen (2011a, b), Jolai et al. (2011), Yucel and Guneri (2011), Liao and Kao (2011), Lin et al. (2011), Govindan et al. (2013), Kilic (2013), Junior et al. (2014), Roshandel et al. (2013), Lee et al. (2015), Igoulalene et al. (2015) and Wood (2016).

VIKOR method Combined with fuzzy set Chen and Wang (2009) and Sanayei et al. (2010) used the fuzzy VIKOR method to evaluate the best supplier. Shemshadi et al. (2011) extended the VIKOR method with a mechanism to extract and deploy objective weights based on Shannon's entropy concept for solving supplier selection. Hsu et al. (2012) select the best vendor for conducting the recycled material based on a hybrid MCDM model combining DEMATELbased on ANP (called DANP) with VIKOR method. You et al. (2015) proposed an extended VIKOR method for group multi-criteria supplier selection with interval 2-tuple linguistic information. Wu et al. (2016) used extended VIKOR under linguistic information for solving supplier selection in nuclear power industry. Ghadikolaei and Parkouhi (2017) used fuzzy analytic network process and grey VIKOR techniques to solve supplier selection problem.

SIR method Chai et al. (2012) proposed a novel intuitionistic fuzzy SIR method to solve the uncertainty group multi-criterion decision-making problem and applied their method in the supplier selection problem.

Best-worst method (BWM) Rezaei et al. (2015a, b) proposed an integrative approach that includes capabilities and willingness as two dimensions for evaluating and subsequently segmenting suppliers. The results of that segmentation are then used as the main basis for supplier development. Rezaei et al. (2016) used the best-worst method to solve supplier selection life cycle approach integrating traditional and environmental criteria.

Outranking synthesis approach In the literature of evaluating and selecting the best supplier, the outranking methods are: ELECTRE and PROMETHEE.

ELimination and Choice Expressing Reality (ELECTRE) Almeida (2007) applied the ELECTRE method to solve an outsourcing contract problem, when dealing with outsourcing vendor selection. Liu and Zhang (2011) proposed a novel method to deal with the supplier selection of supply chains that combines entropy weight and an improved ELECTREIII method. As an example, we mention: Montazer et al. (2009) and Sevkli (2010). Wan et al. (2017) presented an interval 2-tuple ELECTRE II (IT-ELECTRE II) approach to deal with the case of criteria being not compensated in supplier selection problem. Zhong and Yao (2017) proposed an ELECTRE I-based multi-criteria group decision-making method with interval type-2 fuzzy numbers applied to solve supplier selection problem.
Preference Ranking Organisation METHod for Enrichment Evaluations (PROMETHEE) Dulmin and Mininno (2003) used PROMETHEE 1, 2 to solve the supplier selection problem. This approach would be able to deal with several conflicting performance criteria. Araz and Ozkarahan (2007) developed a new multi-criteria sorting method based on PROMETHEE for the supplier evaluation problem. Chen et al. (2011b) used group fuzzy PROMETHEE to solve the real case of the supplier selection problem. After that, PROMETHEE was utilized for ranking the alternatives. Chai et al. (2012) proposed an extended PROMETHEE approach based on superiority and inferiority method. Krishankumar et al. (2017) proposed a new extension to PROMETHEE outranking method under intuitionistic fuzzy set environment for solving supplier selection problem with linguistic preferences.

Segura and Maroto (2017) used PROMETHEE method to develop portfolios with suppliers that should be partners of the company, as well as to identify other types of relationships, such as long-term contracts, market policies or to highlight those to be removed from their portfolio.

\section{Order allocation methods}

In the order allocation problem, the decision maker needs to make more than one decision: What product to order? What quantity to order and from which supplier(s)? In which periods?. Different from single sourcing, in the case of supplier's unreliability or supplier's default, multiple sourcing allows a buyer to order from others suppliers the defect quantity without the need for searching and negotiating with a new supplier.

However, this process involves higher costs than those of single sourcing, owing to the need for managing more than one contract/supplier and the loss of scale economies. In the multiple-sourcing strategies, there are other models of supplier selection where the decision maker has to choose: What to buy and When. As a result, in the multiple-sourcing strategies, two other types can be made to classify the different models. The first type concerns the number of different purchased items, and the second concerns the scheduling horizon (see Table 4, 5 and 6).

Single- and multiple-item models The decision "what to buy" is among the most important decisions in the purchasing operation. In this case, the decision maker has to determine the number of items purchased. In this section, we particularly distinguish two important features: single or multiple products ordered and the presence of any form of quantity discount offered by the vendors.

Single- and multiple-period models The third important decision of the supplier selection problem is "in which peri- 
Table 4 Review of single- and multiple-item models in SSP

\begin{tabular}{|c|c|}
\hline & Review \\
\hline Single-item model & $\begin{array}{l}\text { Ghodsypour and O'Brien (2001), Talluri and } \\
\text { Narasimhan (2003), Kumar et al. (2004, } \\
\text { 2006), Liu et al. (2006), Faez et al. (2009), } \\
\text { Xia and Wu (2007), Liao and Rittscher } \\
\text { (2007a), Demirtas and Üstün (2008), Yu and } \\
\text { Tsai (2008), Glickman and White (2008), } \\
\text { Ozgen et al. (2008), Ustun and Demirtas } \\
\text { (2008), Burke et al. (2008), Sanayei et al. } \\
\text { (2008), Kheljani et al. (2009), Guneri } \\
\text { et al. (2009), Sawik (2010), Sanayei et al. } \\
\text { (2010), Wang and Yang (2009), Lin (2009), } \\
\text { Ebrahim et al. (2009), Kokangul and Susuz } \\
\text { (2009), Demirtas and Üstün (2009), Amid } \\
\text { et al. (2009), Wu et al. (2010), Mendoza } \\
\text { and Ventura (2010), Yucel and Guneri } \\
\text { (2011), Lin et al. (2011), Amid et al. (2011), } \\
\text { Mafakheri et al. (2011), Hajji et al. (2011), } \\
\text { Meena et al. (2011), Xu and Ding (2011), } \\
\text { Lin (2012), Shaw et al. (2012), Mendoza } \\
\text { and Ventura (2012), Glock (2012), Arikan } \\
\text { (2013), Choudhary and Shankar (2013), } \\
\text { Ruiz-Torres et al. (2013), Hammami et al. } \\
\text { (2014), Lee et al. (2013), Sawik (2013), } \\
\text { Ekici (2013), Mohammaditabar et al. (2015), } \\
\text { Mazdeh et al. (2015) }\end{array}$ \\
\hline Multiple-item model & $\begin{array}{l}\text { Crama et al. (2004), Basnet and Leung (2005), } \\
\text { Kawtummachai and Van Hop (2005), Nar- } \\
\text { asimhan et al. (2006), Wang and Che (2007), } \\
\text { Wadhwa and Ravindran (2007), Rezaei and } \\
\text { Davoodi (2008), Bottani and Rizzi (2008), } \\
\text { Wang (2008), Che and Wang (2008), Shen } \\
\text { and Yu (2009), Lee et al. (2009), Onüt et al. } \\
\text { (2009), Amin and Razmi (2009), Yücel et al. } \\
\text { (2009), Osman and Demirli (2010), Chang } \\
\text { and Lee (2010), Amin et al. (2011), Ozkok } \\
\text { and Tiryaki (2011), Li and Zabinsky (2011), } \\
\text { Kara (2011), Rezaei and Davoodi (2011), } \\
\text { Yang et al. (2011), Jolai et al. (2011), Woo } \\
\text { and Saghiri (2011), Bichler et al. (2011), Shi } \\
\text { et al. (2011), Xu and Yan (2011), Mansini } \\
\text { et al. (2012), Senyigit and Soylemez (2012), } \\
\text { Manerba and Mansini (2012), Yu et al. } \\
\text { (2012), Esmaeili et al. (2013), Esfandiari and } \\
\text { Seifbarghy (2013), Sawik (2013), Gorji et al. } \\
\text { (2014), Scott et al. (2015), Cárdenas-Barrón } \\
\text { et al. (2015), Ayhan and Kilic (2015), Yu and } \\
\text { Wong (2015) and Turk et al. (2017) }\end{array}$ \\
\hline
\end{tabular}

ods?" when the buyer decides to define the planning horizon of procurement. Thereby, we have concluded that the techniques developed in the multiple-sourcing strategies can be classified in two models. The single-period models do not consider the inventory management over time, and the multiple-period models consider inventory management by determining an order allocation.

Besides, the suppliers sometimes offer discounts, so that price reductions are designed to induce large orders. Quantity discounts have received significant attention in
Table 5 Review of single- and multiple-period models in SSP

\begin{tabular}{|c|c|}
\hline & Review \\
\hline Single-period model & $\begin{array}{l}\text { Ghodsypour and O'Brien (2001), Talluri and } \\
\text { Narasimhan (2003), Kumar et al. (2004), } \\
\text { Crama et al. (2004), Kawtummachai and } \\
\text { Van Hop (2005), Kumar et al. (2006), } \\
\text { Faez et al. (2009), Narasimhan et al. } \\
\text { (2006), Liao and Rittscher (2007a), Xia } \\
\text { and Wu (2007), Wadhwa and Ravindran } \\
\text { (2007), Wang and Che (2007), Sanayei } \\
\text { et al. (2008), Burke et al. (2008), Ozgen } \\
\text { et al. (2008), Glickman and White (2008), } \\
\text { Yu and Tsai (2008), Demirtas and Üstün } \\
\text { (2008), Wang (2008), Bottani and Rizzi } \\
\text { (2008), Che and Wang (2008), Shen and } \\
\text { Yu (2009), Onüt et al. (2009), Amin and } \\
\text { Razmi (2009), Kheljani et al. (2009), } \\
\text { Sawik (2010), Guneri et al. (2009), Wang } \\
\text { and Yang (2009), Lin (2009), Ebrahim } \\
\text { et al. (2009), Kokangul et al. (2009), } \\
\text { Amid et al. (2009), Yücel et al. (2009), } \\
\text { Wu et al. (2010), Mendoza and Ventura } \\
\text { (2010), Chang and Lee (2010), Amin et al. } \\
\text { (2011), Yucel and Guneri (2011), Lin et al. } \\
\text { (2011), Amid et al. (2011), Ozkok and } \\
\text { Tiryaki (2011), Li and Zabinsky (2011), } \\
\text { Yang et al. (2011), Hajji et al. (2011), Woo } \\
\text { and Saghiri (2011), Bichler et al. (2011), } \\
\text { Meena et al. (2011), Shi et al. (2011), Xu } \\
\text { and Yan (2011), Xu and Ding (2011), Lin } \\
\text { (2012), Shaw et al. (2012), Mendoza and } \\
\text { Ventura (2012), Mansini et al. (2012), } \\
\text { Senyigit and Soylemez (2012), Glock } \\
\text { (2012), Manerba and Mansini (2012), Yu } \\
\text { et al. (2012), Arikan (2013), Ruiz-Torres } \\
\text { et al. (2013), Hammami et al. (2014), } \\
\text { Esmaeili et al. (2013), Ekici (2013), Esfan- } \\
\text { diari and Seifbarghy (2013), Sawik (2013) } \\
\text { and Mohammaditabar et al. (2015) }\end{array}$ \\
\hline Multiple-period model & $\begin{array}{l}\text { Ghodsypour and O'Brien (2001), Basnet and } \\
\text { Leung (2005), Liu et al. (2006), Liao and } \\
\text { Rittscher (2007a, b), Rezaei and Davoodi } \\
\text { (2008), Ustun and Demirtas (2008), } \\
\text { Demirtas and Üstün (2009), Osman and } \\
\text { Demirli (2010), Mafakheri et al. (2011), } \\
\text { Kara (2011), Rezaei and Davoodi (2011), } \\
\text { Jolai et al. (2011), Choudhary and Shankar } \\
\text { (2013), Lee et al. (2013), Sawik (2013), } \\
\text { Gorji et al. (2014), Mazdeh et al. (2015), } \\
\text { Cárdenas-Barrón et al. (2015), Soto et al. } \\
\text { (2017), Ghaniabadi and Mazinani (2017) } \\
\text { and Turk et al. (2017) }\end{array}$ \\
\hline
\end{tabular}

the literature of the supplier selection problem for decades. As a result, the decision of suppliers' selection will be more complicated in the presence of discount schemes. The models developed in the literature which take into account the discounts quantity are as follows: Chauhan and Proth (2003), Crama et al. (2004), Goossens et al. (2007), Burke et al. (2008), Kokangul and Susuz (2009), Zhang (2010), Kang and Lee (2010), Mansini et al. (2012), Lee 
Table 6 Classification of order allocation models

\begin{tabular}{llll}
\hline Models types & $\begin{array}{l}\text { Number of } \\
\text { articles }\end{array}$ & $\begin{array}{l}\text { Percentage } \\
\text { local \% }\end{array}$ & $\begin{array}{l}\text { Percent- } \\
\text { age global } \\
\%\end{array}$ \\
\hline Number total of papers & 175 & & \\
Single-item models & 47 & 26.85 & 17.40 \\
Multiple-item models & 41 & 23.42 & 15.18 \\
Single-period model & 66 & 37.71 & 24.44 \\
Multiple-period models & 21 & 12 & 7.78 \\
\hline
\end{tabular}

et al. (2013), Choudhary and Shankar (2013, 2014), Mazdeh et al. (2015), Ayhan and Kilic (2015), etc.

Single-objective optimization models By considering the literature of published works for multiple-sourcing supplier selection, we can distinguish two groups of techniques used to model the supplier selection problem (SSP) such as (1) single-objective optimization and (2) multi-objective optimization. In the single-objective models, only one criterion is considered as the objective function, while the other criteria, such as quality and led-time, are modeled as constraints. These models can be divided into the following categories: linear programming, linear/nonlinear mixed programming, etc.

Linear programming (LP) Talluri and Narasimhan (2003) are the first researchers who considered the performance variability measures in evaluating different suppliers by developing two linear programming models to maximize and minimize the performance of a supplier against the best target measures set by the buyer. $\mathrm{Ng}$ (2008) developed a weighted linear programming model to help decision makers or buyers to solve the supplier selection problem, with an objective of maximizing the supplier's score. Che and Wang (2008) used a linear programming to model the supplier's selection and order quantity allocation problems to find the fundamental purchasing configuration that will best minimize the T-score total utility function of total products.

Integer programming (IP) Talluri (2002) developed a binary integer linear programming model to evaluate the alternative supplier bids based on ideal targets of bid attributes set by the buyer and to select an optimal set of bids by matching the demand and capacity constraints. Hong et al. (2005) proposed a model based on mixed integer linear programming (MILP) for the supplier selection problem. The main objective of this model is to determine the optimal number of suppliers and the order quantity. Basnet and Leung (2005) presented a mixed linear programming model that combines the supplier selection with the traditional inventory lot sizing. Liu et al. (2006) developed an integer programming to solve the distributed planning problem. Glickman and White (2008) developed a mixed integer linear programming (MILP) model to find out a solution for the supplier selection problem when multiple products are transported via truckload and less than truckload shipment to a number of distributed centers. Rezaei and Davoodi (2008) proposed a mixed integer programming model in which they introduced imperfect items and storage capacity in the lot sizing with the supplier selection problem. Keskin et al. (2010) considered the inventory-related costs and decisions of the stores. Mansini et al. (2012) developed an integer programming-based heuristics to solve the supplier selection problem with quantity discounts and truckload shipping. Choudhary and Shankar (2013) proposed an integer linear programming model to determine the timings of procurement, lot sizes, suppliers and carriers to be chosen so as to incur the least total cost over the planning horizon. Palak et al. (2014) proposed a mixed linear programming in order to minimize the total supply chain costs. Cárdenas-Barrón et al. (2015) proposed a novel approach to find a solution of the multi-product multi-period inventory lot sizing with supplier selection problem. Ayhan and Kilic (2015) provided a two-stage approach integrating both the F-AHP technique and the MILP model to solve the supplier selection problem in multi-item/multi-supplier environment with all-unit quantity discount allowed. Adeinat and Ventura (2015) developed a mixed integer nonlinear programming to search the replenishment policy and optimal selling price in a supply chain for a particular type of product defined by a single retailer and multiple potential suppliers. Ghaniabadi and Mazinani (2017) developed a mixed integer linear programming to solve the dynamic lot-sizing problem with supplier selection, backlogging and quantity discounts.

Nonlinear programming (NLP) Ghodsypour and O'Brien (2001) formulated a mixed integer nonlinear programming (MINLP) model to solve the supplier selection problem. Crama et al. (2004) described the purchasing decisions faced by a multi-plant company. They formulated a nonlinear mixed binary programming to solve cost-minimization problem. Kheljani et al. (2009) proposed a number of mixed integer nonlinear programming models to model the supplier selection problem. Keskin et al. (2010) proposed a MINLP model for the supplier selection with inventory problem of a multi-store firm. Esmaeili et al. (2013) investigated a nonlinear binary programming to integrate a multi-item supplier selection model. Ekici (2013) applied a mixed integer nonlinear programming model for the supplier selection under capacity constraint and multiple criteria. Mohammaditabar et al. (2015) analyzed the selected suppliers and prices that are agreed on in decentralized supply chains. Mazdeh et al. (2015) developed a mixed integer nonlinear programming (MINLP) model for the dynamic lot-sizing problem with supplier selection and quantity discounts. Pazhani et al. (2016) proposed a mixed integer nonlinear programming model to determine the optimal inventory policy for the 
stages in the supply chain and allocation of orders among the suppliers considering inventory replenishment, holding and transportation costs simultaneously. Ahmad and Mondal (2016) developed a mathematical model based on mixed integer nonlinear programming (MINLP) to solve dynamic supplier selection problem (DSSP). Soto et al. (2017) addressed the multi-period inventory lot-sizing problem with supplier selection and inventory shortage, and it considers both all-units and incremental quantity discounts.

Dynamic programming (DP) Li et al. (2009) considered a supply contracting problem in which the buying firm faces non-stationary stochastic price and demand. Tsai et al. (2010) proposed an approach to model the supplier selection problem in a dynamic environment. Hajji et al. (2011) developed a dynamic stochastic optimization model for the joint supplier selection, replenishment and manufacturing control problem. Ventura et al. (2013) developed a mixed integer nonlinear programming model to determine an optimal inventory policy that coordinates the transfer of materials between consecutive stages of the supply chain from period to period while properly placing the purchasing orders to the selected suppliers and satisfying customer demand on time. Choi (2013) proposed a two-phase optimal supplier selection scheme in which the first phase filters the inferior suppliers and the second phase helps to select the best supplier among the set of non-inferior suppliers by multistage stochastic dynamic programming. Mazdeh et al. (2015) developed single-item dynamic lot-sizing problem with supplier selection and quantity discounts. Ahmad and Mondal (2016)solved a dynamic supplier selection problem (DSSP) under two-echelon supply network with assembly of the part-product. Ghaniabadi and Mazinani (2017) studied the dynamic lot-sizing problem with supplier selection, backlogging and quantity discounts.

Stochastic programming (SP) Xu and Nozick (2009) formulated a two-stage stochastic program and a solution procedure to optimize the supplier selection to hedge against disruptions. Awasthi et al. (2009) considered a supplier selection problem for a single manufacturer/retailer when a demand is random. Zhang and Zhang (2011) developed a mixed integer programming model to model the supplier selection and purchasing problem with fixed selection cost and limitation on minimum and maximum order sizes under stochastic demand. Kara (2011) proposed an integrated methodology for the supplier selection problem based on two-stage stochastic programming model and fuzzy TOPSIS methods in this methodology. Li and Zabinsky (2011) developed a scenario-based two-stage stochastic programming (SP) model and a chance-constrained model for the supplier selection which considered the case of multiple plants with multiple products. Yang et al. (2011) proposed a stochastic demand of multi-product supplier selection model with service level and budget constraints using genetic algorithm. Ruiz-Torres et al. (2013) considered the supplier's order allocation problem in the context of a classic transportation network with multiple supply sources and a set of separate demand points, where each supplier not only has limited capacity, but also a probability of failure to supply the required quantity. Sawik (2013) proposed a portfolio approach and developed a mixed integer programming model with conditional value-at-risk for the selection and protection of suppliers and the order allocation quantity and emergency inventory in the supply chains with disruption risks. Guo and Li (2014) studied the supplier selection and order allocation problem in a multi-echelon system under a stochastic demand. Hammami et al. (2014) proposed a mixed integer stochastic programming model for the supplier selection in the global context. Sawik (2014) formulated a stochastic mixed integer programming approach to the integrated supplier selection and customer order scheduling in the presence of supply chain disruption risks, for a single- or dual-sourcing strategy. Scott et al. (2015) proposed a hybrid method based on AHP, QFD and stochastic optimization for selecting the appropriate suppliers and allocating order between them. Torabi et al. (2015) proposed a two-stage stochastic programming model for solving supplier selection and order allocation problem to build the resilient supply base under operational and disruption risks.

Fuzzy linear programming Guneri et al. (2009) presented an integrated fuzzy and linear programming approach to the supplier selection problem in the supply chain. Hsu et al. (2010) proposed an approach for the selection of suppliers which is capable of handling fuzzy data but was not seriously treated by the researchers. Amin et al. (2011) proposed a decisional method to select the suppliers based on two phases. In the first phase, they applied a quantified SWOT analysis (strengths, weaknesses, opportunities and threats) to evaluate the suppliers. In the second phase, they developed a fuzzy linear programming model to determine the order quantity. Chen et al. (2011a) developed an approach to tackle multiple-criteria group decision-making problems in the context of interval-valued intuitionistic fuzzy sets.

Multi-objective optimization models In this section, we are interested in the multi-objective optimization that is an area of multiple-criteria decision making combined with the mathematical optimization involving more than one objective function to be simultaneously optimized. For the supplier selection problem, we classify the multi-objective optimization models in the following categories:

Multiple-objective linear programming (MOLP) Narasimhan et al. (2006) constructed a multi-objective programming model to select the optimal suppliers and determine the optimal order quantity. Sodenkamp et al. (2016) integrated multi-criteria decision method and linear programming for 
developing to support collaborative multi-objective supplier selection and order allocation decisions.

Multiple-objective mixed integer programming (MIP) Xia and $\mathrm{Wu}$ (2007) incorporated into the supplier selection the multi-objective mixed integer programming model with the AHP. Sawik (2010) established single- and multi-objective mixed integer programming models, where the selection of suppliers is based on price and quality of the purchased parts and reliability of on time delivery. Feng et al. (2011) introduced a multiple-objective $0-1$ programming model for the supplier selection problem. Rezaei et al. (2015a, b) proposed a mixed multi-objective programming to solve lot sizing with supplier selection for an assembly system.

Multiple-objective nonlinear programming (NLP) Cakravastia and Takahashi (2004) developed a multi-objective nonlinear model for the negotiation process by generating a set of effective alternatives in each negotiation period. Furthermore, Rezaei and Davoodi (2011) developed two multi-objective mixed integer nonlinear models for multiperiod lot-sizing problems involving multiple products and multiple suppliers. Esfandiari and Seifbarghy (2013) modeled the supplier quota allocation problem as a multi-objective nonlinear optimization problem, while the demand was dependent on the offered price by the suppliers.

Dynamic multiple-objective programming Liao and Rittscher (2007a) developed a multi-objective programming model, integrating supplier selection, procurement lot sizing and carrier selection decisions for a single purchasing item over multiple planning periods while the demand quantities are known but inconstant, i.e., dynamic demand conditions. Ware et al. (2014) developed a multi-objective mixed integer nonlinear program (MINLP) to address the dynamic supplier selection problem (DSSP):

Stochastic multiple-objective programming For the stochastic multiple-objective programming, Liao and Rittscher (2007b) formulated a multi-objective programming model for the supplier selection under stochastic demand conditions. Ravindran et al. (2010) developed a multi-objective optimization model for the supplier selection problem which accounted for value-at-risk type of disruption due to natural events and miss-to-target type of risk of quality. Xu and Ding (2011) used a chance-constrained MOLP model with bi-random coefficients to model the supplier selection problem. Senyigit and Soylemez (2012) considered the lot sizing with the supplier selection problem in multi-echelon multi-product defective supply chain network with stochastic demand.

Fuzzy multiple-objective programming Amid et al. (2006) presented a fuzzy multi-objective linear programming model for supplier selection when the input data are vagueness and imprecision. Kumar et al. (2006) proposed a fuzzy programming model for the vendor selection problem in a supply chain as a "fuzzy multi-objective integer programming vendor selection problem" formulation. Recently, Wu et al. (2010) have presented a fuzzy multi-objective programming model to decide on the supplier selection taking risk factors into consideration. Ozkok and Tiryaki (2011) proposed a compensatory fuzzy approach to solve the multi-objective linear supplier selection problem with multiple-item (MLSSP-MI) by using Werners' "fuzzy AND” operator. Haleh and Hamidi (2011) developed a fuzzy linear programming model to optimize a fuzzy MCDM model to allocate orders to the suppliers in a supply chain under uncertainty over a multi-period time horizon. Yucel and Guneri (2011) developed a weighted additive fuzzy programming approach for multi-criteria supplier selection. Arikan (2013) studied the multiple-sourcing supplier selection problems as a fuzzy multi-objective linear programming problem. Dursun and Karsak (2013) considered the QFD planning, which incorporates two interrelated HOQ matrices, as a fuzzy multi-criteria group decision tool and employed the fuzzy weighted average (FWA) method. Similarly, Lin (2012), Yu et al. (2012), Shaw et al. (2012), as well as Amin and Zhang (2012), Moghaddam (2015) used the multi-objective fuzzy linear programming to solve the supplier selection problem. The fuzzy multiple-objective mixed integer linear programming is developed by Razmi et al. (2009a), Wang and Yang (2009), Amid et al. (2009) and Nazari-Shirkouhi et al. (2013).

Bi-objective optimization Sawik (2011a, b, c) considered the risk-neutral and risk-adverse objective functions separately and simultaneously in a bi-objective optimization problem. Mafakheri et al. (2011) proposed a two-stage multiple-criteria dynamic programming approach for the supplier selection and order allocation. In the first stage, they employed the AHP to rank the suppliers and in the second stage, they integrated the supplier ranks into an order allocation model that aims to maximize a utility function and minimize the total supply chain costs. Turk et al. (2017) proposed bi-objective model to solve inventory planning with supplier selection.

Goal programming (GP) Karpak et al. (2001) proposed a goal programming (GP) model to evaluate the suppliers through three objectives identified such as quality, cost and delivery performance. Kumar et al. (2004) used the multi-objective model containing three fuzzy goals and some crisp constraints for the supplier selection problem. They also applied the goal programming approach to solve this model. Osman and Demirli (2010) proposed a bilinear goal programming model to represent the strategic reconfiguration and to formulate the supplier selection problem. Chen (2011a, b) integrated multiple MP techniques among which GP is an important component. Lee et al. (2009) and Liao and Kao (2011) reduced real-world SS problems to a formulation of multi-choice GP. Sadeghieh et al. (2012) developed a genetic algorithm (GA)-based grey GP 
Table 7 Classification of mathematical models in SSP

\begin{tabular}{|c|c|c|c|c|}
\hline \multirow[t]{2}{*}{ Multiple-sourcing models } & \multirow{2}{*}{$\begin{array}{l}\text { Models types } \\
\text { Total number of papers }\end{array}$} & \multirow{2}{*}{ 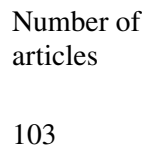 } & \multirow[t]{2}{*}{$\begin{array}{l}\text { Percentage local } \\
\%\end{array}$} & \multirow[t]{2}{*}{$\begin{array}{l}\text { Percent- } \\
\text { age global } \\
\%\end{array}$} \\
\hline & & & & \\
\hline \multirow[t]{6}{*}{ Single-objective programming } & Linear programming & 03 & 2.91 & 1.11 \\
\hline & Integer Programming & 15 & 14.56 & 5.56 \\
\hline & Nonlinear programming & 11 & 10.67 & 4.07 \\
\hline & Dynamic programming & 08 & 7.76 & 2.96 \\
\hline & Stochastic programming & 13 & 12.62 & 4.81 \\
\hline & Fuzzy programming & 04 & 3.88 & 1.48 \\
\hline \multirow[t]{8}{*}{ Multi-objective programming } & Multiple-objective linear programming & 02 & 1.94 & 0.74 \\
\hline & Multiple-objective mixed integer programming & 04 & 3.88 & 1.48 \\
\hline & Multiple-objective nonlinear programming & 03 & 2.91 & 1.11 \\
\hline & Dynamic multiple-objective programming & 02 & 1.94 & 0.74 \\
\hline & Stochastic multiple-objective programming & 04 & 3.88 & 1.48 \\
\hline & Fuzzy multiple-objective programming & 17 & 16.50 & 6.29 \\
\hline & Bi-objective programming & 05 & 4.85 & 1.85 \\
\hline & Goal programming & 12 & 11.65 & 4.44 \\
\hline
\end{tabular}

Table 8 Classification of order allocation methods

\begin{tabular}{lllll}
\hline Multiple-sourcing methods & Methods & $\begin{array}{l}\text { Number of } \\
\text { articles }\end{array}$ & $\begin{array}{l}\text { Percentage } \\
\text { local } \%\end{array}$ & $\begin{array}{l}\text { Percent- } \\
\text { age global } \\
\%\end{array}$ \\
& Total number of papers & 42 & & \\
\hline Exact methods & Branch and bound & 03 & 7.14 & 1.11 \\
& Branch and cut & 01 & 2.38 & 0.37 \\
& Benders decomposition method & 01 & 2.38 & 0.37 \\
Artificial intelligence method & Genetic algorithm & 14 & 33.33 & 5.18 \\
& Neural network & 10 & 23.80 & 3.70 \\
& Grey system theory & 05 & 11.90 & 1.85 \\
& Particle swarm optimization & 04 & 9.52 & 1.48 \\
& Ant colony algorithm & 01 & 2.38 & 0.37 \\
& Scatter search algorithm & 01 & 2.38 & 0.37 \\
& Evolutionary algorithm & 02 & 4.76 & 0.74 \\
\hline
\end{tabular}

approach. Aouadni et al. (2013) developed the imprecise GP model with satisfaction function to explicitly incorporate the preferences of the buyer in all the decision-making to solve the supplier selection problem. Finally, Choudhary and Shankar (2014) used a goal programming model for joint decision making of inventory lot size for the supplier selection and the carrier selection. Jadidi et al. (2015) proposed an improved multi-choice goal programming (MCGP) approach for solving supplier selection problem. Moghaddam (2015) used a Monte Carlo simulation model integrated with fuzzy goal programming to determine the best set of suppliers and the optimal order allocation in reverse logistics with demand uncertainty. Igoulalene et al. (2015) combined the fuzzy consensus-based neat OWA and goal programming model to solve multi-criteria group decision-making supplier selection problem. Table 7 classifies the different mathematical models in SSP.

The math models may be solved in different ways. The approaches used in solving them are outlined in the following section. We classify the solving mathematical models in two main categories such as exact methods and artificial intelligence (AI) methods (see Table 8).

Exact method Branch-and-bound method Basnet and Leung (2005) used an enumerative search algorithm and a heuristic to solve a multi-period inventory lot-sizing scenario, where there are multiple products and multiple suppliers. Goossens et al. (2007) studied the procurement 
problem faced by a buyer who needs to purchase a variety of goods from suppliers applying a total quantity discount policy. They performed computational experiments by comparing three exact algorithms: a min-cost flow-based branch-and-bound approach (using the network solver of Ilog Cplex 8.1), a linear programming based branch-andbound approach (using the MIP solver of Ilog Cplex 8.1) and a branch-and-cut approach (also using the MIP solver of Ilog Cplex 8.1). Zhang and Zhang (2011) addressed the supplier selection and purchase problem under stochastic demand. The problem is modeled as a mixed integer programming (MIP), and a branch-bound algorithm is proposed to solve it.

Branch-and-cut method In 2012, Manerba and Mansini provided a branch-and-cut method to solve the capacitated total quantity discount problem (Capacitated TQDP) where the quantity available for a product from a supplier is limited.

Benders decomposition method Osman and Demirli (2010) developed a bilinear goal programming model to represent the strategic reconfiguration and the supplier selection problem. The Benders decomposition algorithm is used to handle the complexity of this model.

Artificial intelligence (AI) techniques In the literature of the supplier selection, the major artificial intelligence techniques are genetic algorithm (GA), neural network (NN), rough set theory (RST) and grey system theory (GST).

Genetic algorithm $(G A)$ The literature that considered typical GA for the supplier selection problem includes: Wang and Che (2007), Liao and Rittscher (2007a), Che and Wang (2008), Rezaei and Davoodi (2008), Yang et al. (2011) and Lee et al. (2013). Moreover, Xu and Ding (2011) designed a bi-random simulation-based GA. Che (2010) provided a heuristic algorithm combining guided GA and Pareto GA. In addition, Wang (2008), as well as Sadeghieh et al. (2012) utilized GA as an element to construct their decision model to solve the supplier selection problem. Rezaei and Davoodi (2011) applied a non-dominated sorting GA (NSGA II) to solve the multi-objective nonlinear programming model for a joint pricing, lot sizing and supplier selection model. Deng et al. (2014) formulated a multi-objective optimization problem for the supplier selection and a product line design, and it is solved by using NSGA II. Simić et al. (2015) presented a novel hybrid model for supplier assessment and selection, based on hybrid solution including genetic algorithm (GA) and harmony search algorithm (HSA). Du et al. (2015) proposed a hybridization of Pareto genetic algorithm (PGA) with multi-intersection and similarity crossover (MSC) strategy to solve the bi-objective program of the life cycle supplier selection of CoPS (LSS\&CoPS) problem.

Neural network $(N N)$ The neural network was used in the SSP are: Keskin et al. (2010), Luo et al. (2009), Celebi and Bayraktar (2008), Wu (2009a), Lee and Ouyang (2009), Keskin et al. (2010), Guneri et al. (2011), Aksoy and Öztürk (2011), Kar (2015) and Tavana et al. (2016).

Grey System Theory (GST) The reviewed literature introduced GST for SSP from two perspectives: the decision information in the form of grey values (Bai and Sarkis 2010; Sadeghieh et al. 2012) and grey relational analysis (GRA) (Golmohammadi and Mellat-Parast 2012; Li et al. 2008; Wu 2009b).

Particle swarm optimization (PSO) Kuo et al. (2010) proposed decision support system composed of three components such as the collection of quantitative data, a combined particle swarm optimization (PSO) and fuzzy neural network (FNN) to derive the rules for qualitative data, and a decision integration model for integrating both the quantitative data and fuzzy knowledge decision to achieve the optimal decision an intelligent supplier decision support system. Assadipour and Razmi (2012) developed PSO algorithm to find good feasible solutions to the problem of inventory lot sizing and supplier selection for an assembly system, where the supplier's available capacities are assumed as ambiguous dynamic parameters. Xiao et al. (2012) developed a novel evaluation framework to select the supplier's considering risk by integrating fuzzy cognitive map (FCM) and fuzzy soft set to solve the supplier selection problem. The PSO algorithm was used to train fuzzy cognitive maps and obtain the weight of each criterion. Kuo et al. (2015) proposed an integrated artificial immune network and particle swarm optimization to distribute the order quantity between the key suppliers at minimum cost.

Ant colony algorithm (ACA) Tsai et al. (2010) used an attribute-based ant colony system for the supplier evaluation.

Scatter search algorithm Ebrahim et al. (2009) used the scatter search algorithm for supplier selection and order lot sizing under multiple price discount environment.

Evolutionary algorithm (EA) Soto et al. (2017) combined evolutionary and local research to solve lot sizing with supplier selection, inventory shortage and quantity discounts. Turk et al. (2017) utilized multi-objective evolutionary algorithm (MOEA) to minimize the conflicting objectives of supply chain operation cost and supplier risk.

\section{Hybrid methods}

In the last decade, numerous integrated approaches to the supplier selection have been proposed. We mentioned among these integrated methods the combination between MCDM methods, such as Hsu et al. (2012) combined ANP and VIKOR method. Onüt et al. (2009) combined ANP and TOPSIS methods. Shirinfar and Haleh (2011) used fuzzy ANP, fuzzy TOPSIS and fuzzy PROMETHEE. Furthermore, there are other types of hybridization as: Yang and Chen (2006) integrated AHP and grey relational analysis. Kar 
Table 9 Review of hybrid methods in SSP

\begin{tabular}{|c|c|c|}
\hline Methods & Technique & Additional features of decision approaches and literature \\
\hline \multirow[t]{13}{*}{ Certitude hybrid approach } & \multirow[t]{2}{*}{ AHP, GP } & Lexicographic goal programming (Çebi and Bayraktar (2003)) \\
\hline & & Product-driven supply chain selection (Wang et al. $(2004,2005)$ ) \\
\hline & \multirow[t]{2}{*}{ ANP, LP } & Benefit, opportunity, cost and risk model (Demirtas and Üstün (2008)) \\
\hline & & Benefit, opportunity, cost and risk model (Demirtas and Üstün (2008)) \\
\hline & \multirow[t]{2}{*}{ ANP, GP, LP } & Benefit, opportunity, cost and risk model (Demirtas and Üstün (2009)) \\
\hline & & Imprecise GP integrated the decision maker's preference (aouadni et al. (2013)) \\
\hline & ANP, TOPSIS, LP & Case study related to manufacturing enterprise (Lin et al. (2011)) \\
\hline & ANP, NLP & Mixed integer NLP (Razmi and Rafiei (2010)) \\
\hline & MAUT, LP & Maximize total additive utility (Sanayei et al. (2008)) \\
\hline & ANP, VIKOR & Recycled materials (Hsu et al. (2012)) \\
\hline & TOPSIS, Max-Min GP & Normalized goal programming (Jadidi et al. (2014)) \\
\hline & AHP, MAUT, PROMETHEE & Supplier segmentation (Segura and Maroto (2017)) \\
\hline & ANP, ELECTRE II & Supplier selection in interval 2-tuple linguistic environment (Wan et al. (2017)) \\
\hline \multirow[t]{16}{*}{ Fuzzy hybrid approach } & AHP, LP & Fuzzy weighted average used in Fuzzy QFD (Dursun and Karsak (2013)) \\
\hline & AHP, MOP, LP & Fuzzy compromise programming (Wang and Yang (2009) \\
\hline & AHP, GP & Multiple goal programming (Lee et al. (2009)) \\
\hline & \multirow[t]{2}{*}{ AHP, MOP } & Low carbon SCM (Shaw et al. (2012)) \\
\hline & & Soft time window (Yu et al. (2012)) \\
\hline & MOP, LP, ANP & Fuzzy multi-objective LP (Lin (2012)) \\
\hline & ANP, NLP & Network formation and pairwise comparisons (Razmi et al. (2009a)) \\
\hline & \multirow[t]{2}{*}{ ANP, DEMATEL } & Group fuzzy TOPSIS integrated with fuzzy LP (Razmi et al. (2009b)) \\
\hline & & LP model under fuzzy environments (Guneri et al. (2009)) \\
\hline & \multirow[t]{2}{*}{ TOPSIS, LP } & Group weighted additive fuzzy programming (Yucel and Guneri (2011)) \\
\hline & & Fuzzy TOPSIS (Kara (2011)) \\
\hline & SP, TOPSIS & $\begin{array}{l}\text { Single buyer, multiple products, multiple suppliers and multiple periods (Jolai et al. } \\
\text { (2011)) }\end{array}$ \\
\hline & \multirow[t]{2}{*}{ TOPSIS, GP } & Group multi-choice goal programming (Liao and Kao (2011)) \\
\hline & & $\begin{array}{l}\text { Fuzzy TOPSIS and multi-choice goal programming (Rouyendegh and Saputro } \\
\text { (2014)) }\end{array}$ \\
\hline & \multirow[t]{2}{*}{ TOPSIS, MILP } & Supplier selection in multi-item/multi-supplier environment (Kilic (2013)) \\
\hline & & Supplier evaluation and demand allocation (Singh(2014)) \\
\hline
\end{tabular}

(2015) presented a hybrid approach for group decision support for the supplier selection problem based on the fuzzy set theory, analytic hierarchy process and neural networks. Ha and Krishnan (2008) integrated AHP, DEA and artificial neural network; Saen (2007a) and Sevkli et al. (2007) integrated AHP and DEA, etc. In this paper, we are interested in summarizing the hybridization methods between MCDM method and the optimization models to evaluate and select the suppliers and determine the order allocation among them. Then, we provide an overall summary of these methods in Table 9.

\section{Observations and remarks}

Figure 2 presents the classification of the MCDM method based on years. Since 2007, there was a considerable growth in the number of articles applied MCDM methods on the supplier selection problem. There are clear that the AHP method is the most frequent method applied in this field. The total number of articles that used the AHP method published since 2000 is $38.52 \%$. Another interesting result shows that the TOPSIS method is the important method used in 2011. The usage of MCDM method has decreased since 2013, but lots of attention was paid to hybrid method, mathematical models and artificial method in recent 5 years.

The distribution of the mathematical models by years is shown in Fig. 3. This clearly illustrates the orientation toward mathematical modeling and the artificial 
Fig. 2 Distribution of the MCDM methods by years
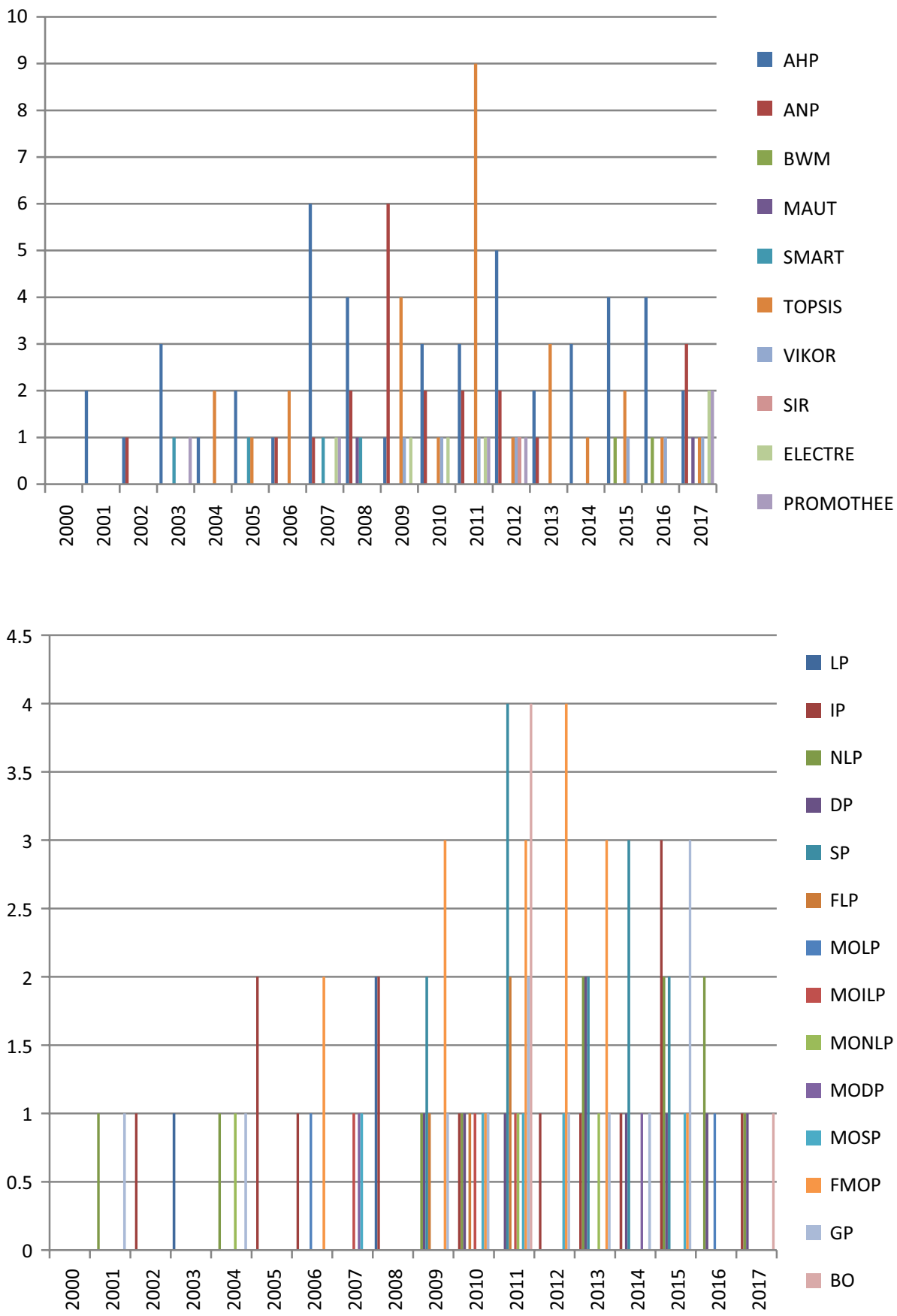

Fig. 3 Distribution of the mathematical models based on years
Overall, among the objectives of this survey is to find out the most popular method adopted in supplier selection and order allocation literature. As found in the previous sections, the MCDM approaches (122 papers or 45.18\%) remain more popular than the mathematical programming (103 or $38.14 \%$ ) and $\mathrm{AI}$ approaches (42 papers or $15.55 \%$ ) as a tool for solving this problem. We summarize in Table 10 the strengths and weaknesses of the different methods.

It we found that $50.76 \%$ of these models have been applied in real-world cases and the most of them in manufacturing companies (40 articles) (see Fig. 4). 
Table 10 The strengths and weaknesses of supplier selection methods

\begin{tabular}{|c|c|c|c|}
\hline \multicolumn{2}{|l|}{ Methods } & Strengths & Weaknesses \\
\hline \multirow{3}{*}{\multicolumn{2}{|c|}{ MCDM }} & Quick and easy to use & Depends on human judgment \\
\hline & & Takes into account qualitative and quantitative & $\begin{array}{l}\text { No possibility to introduce constraints in the } \\
\text { model pairwise comparison matrices is a }\end{array}$ \\
\hline & & Considers the dependency between criteria & $\begin{array}{l}\text { complex task } \\
\text { Non-meaningfulness of the resulting rankings in } \\
\text { mixed data contexts }\end{array}$ \\
\hline \multirow[t]{5}{*}{ Mathematical programming } & Mono-objective & Finds optimal solution & Doesn't take into consideration human judgment \\
\hline & & $\begin{array}{l}\text { Possibility of introducing new constraints in } \\
\text { model }\end{array}$ & $\begin{array}{l}\text { Difficult to measure qualitative criteria } \\
\text { Computing optimal solution might be time-con- } \\
\text { suming in the case of NP-hard problems }\end{array}$ \\
\hline & Multi-objective & $\begin{array}{l}\text { Criteria do not necessarily have a common } \\
\text { dimension, finds several solutions }\end{array}$ & $\begin{array}{l}\text { Difficulty to take into account human judgment } \\
\text { Doesn't obtain optimal solution }\end{array}$ \\
\hline & & We can introduce new constraints & Difficult to analyze the result \\
\hline & & & $\begin{array}{l}\text { Computing near solution might be time-con- } \\
\text { suming in the case of NP-hard problems }\end{array}$ \\
\hline \multicolumn{2}{|l|}{ Exact methods } & $\begin{array}{l}\text { Provides optimal solution } \\
\text { High quality of solution }\end{array}$ & Doesn't take into consideration human judgment \\
\hline \multirow{3}{*}{\multicolumn{2}{|c|}{ Artificial intelligence }} & & \\
\hline & & Takes into account qualitative criteria & access to expertise is long and difficult \\
\hline & & & Very expensive \\
\hline
\end{tabular}

Application of research papers from 2000 to 2017

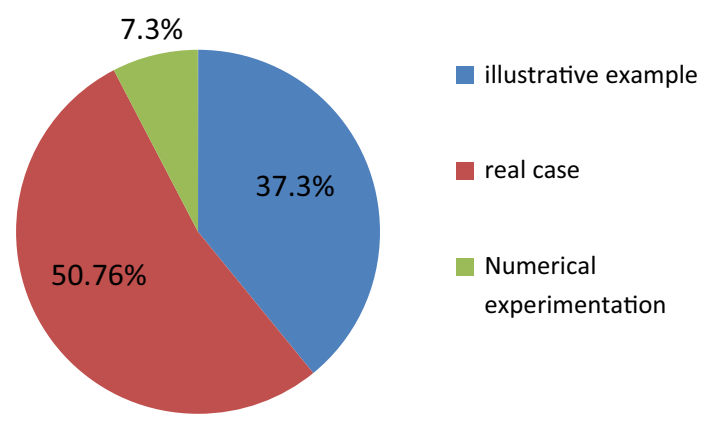

Fig. 4 Distribution of the application models

\section{Conclusion and future directions}

This paper attempted to review papers published in the period 2000-2017 about supplier selection and order allocation issues. There are 270 international journals studied in this survey, which are accessible via the database system Web of Science. As can be seen, most papers have been published in journals with strong quantitative traditions. The majority of these papers appear in Expert Systems with Applications (64 articles), International Journal of Production Economics (35 articles) and European Journal of Operational Research (26 articles) and others (these are listed in Table 1).

The first aim of this survey was to systematically review the studies conducted based on the problem of supplier selection and order allocation since 2000. The total of 270 published articles about this field were systematically and carefully selected and summarized. In this paper, we determined firstly the main tools that have been employed in the domain of supplier selection and order allocation about the recent 17 years. Secondly, we provided the most international journals published articles related to these problems. Thirdly, we demonstrated the different years when authors published articles related to these fields.

The supplier selection with order allocation problem has attracted the interest of many researchers, and the number of research studies on this topic has increased in the last years. Several multi-criteria decision-making methods (MCDM) have been proposed in the literature to select suppliers which include both qualitative and quantitative criteria. According to the results obtained in this systematic review, we found that the number of pre-selection methods is limited despite this step is very important in the supplier selection process. This screening process makes identifying a suitable subset of suppliers and reduces the large set of initial suppliers to a smaller manageable set of acceptable suppliers by ranking them under a pre-defined set of criteria. Among the benefits of this pre-qualification step is that the possibility of rejecting good suppliers at an early stage is reduced.

On the contrary, authors paid attention to MCDM methods and integrated methods because the supplier selection problem is multi-criteria decision-making problem which includes qualitative and quantitative criteria. These methods are very quick and easy to use, but they depend on human judgment because the different weights given to the 
various attributes depend on the decision makers' subjective judgment.

Also, we showed that the AHP method is the most popular MCDM method used in this field area by 46 articles and the second approach is the TOPSIS. The AHP method has more several criticisms such as the rank reversal of the alternatives. Then, we found that the applied MCDM methods in this field suffer from two major shortcomings: (1) the non-meaningfulness of the resulting rankings in mixed data contexts (i.e., the rankings of alternatives may change under admissible transformations of the initial attribute values, in the measurement-theoretic sense of the term) and (2) rank reversals that the rankings of alternatives may change if a new alternative is added or an old one is deleted from it or replaced in it).

In this board literature, several recent studies have pointed out to the importance of the order allocation problem in the supplier selection issue which is considered most important functions to be performed by the purchasing decision makers. For finding the best solution for the flowing decision "what to buy?", "in which period?", many mathematical programming models have been developed in the recent years in this context. It may also be argued that the mathematical programming models are more objective than MCDM methods because the decision maker can define explicitly the objective function.

In this review, we classified the order allocation problem in two strategies: single-sourcing problem (47 articles considered the single-item models and 41 articles the multiple-item models) and multiple- or dual-sourcing problems (66 articles studied the case of the single-period model and 21 papers the case of multi-period models). Moreover, we classified the mathematical models according to the objective function as either a single-objective function or multiple-objective functions. Besides, we discussed the different methods used in the literature to solve these models. Yet we found that the most popular of these models are a real practical case in the industrial sector by 137 articles. Nowadays, quantitative methods received more attention in recent researches in this domain. The authors are based in their researches on the exact method or intelligence artificial approaches to solve these mathematical programming according the complexity of the problem.

There is an overall suggestion for future research that may be pursued. Firstly, we propose to make the MCDM methods able to handle properly mixed attribute values because the attribute values have different levels of measurement. Secondly, we should take into consideration the rank reversal problem in MCDM method because the final rank of alternatives in the global ranking can be reversed when a new alternative is removed or added from the initial set of alternatives.
Thirdly, we will suggest applying the exact method such as branch and bound to solve the NP-hard problems in the supplier selection and order allocation problem for finding the optimal solution. Finally, during that time the researchers did not give attention to apply these methods in service industries and sectors as well.

Open Access This article is distributed under the terms of the Creative Commons Attribution 4.0 International License (http://creativeco mmons.org/licenses/by/4.0/), which permits unrestricted use, distribution, and reproduction in any medium, provided you give appropriate credit to the original author(s) and the source, provide a link to the Creative Commons license, and indicate if changes were made.

\section{References}

Adeinat H, Ventura AJ (2015) Determining the retailer's replenishment policy considering multiple capacitated suppliers and pricesensitive demand. Eur J Oper Res 247(2015):83-92

Ahmad MT, Mondal S (2016) Dynamic supplier selection model under two-echelon supply network. Expert Syst Appl 65:255-270

Aissaoui N, Mohamed H, Elkafi H (2007) Supplier selection and order lot sizing modeling: a review. Comput Oper Res 34:3516-3540

Akarte MM, Surendra NV, Ravi B, Rangaraj N (2001) Web based casting supplier evaluation using analytical hierarchy process. J Oper Res Soc 52(5):511-522

Aksoy A, Öztürk N (2011) Supplier selection and performance evaluation in just-in-time production environments. Expert Syst Appl 38:6351-6359

Almeida AT (2007) Multicriteria decision model for outsourcing contracts selection based on utility function and ELECTRE method. Comput Oper Res 34:3569-3574

Amid A, Ghodsypour SH, O’Brien C (2006) Fuzzy multiobjective linear model for supplier selection in a supply chain. Int J Prod Econ 104(2):394-407

Amid A, Ghodsypour SH, O'Brien C (2009) A weighted additive fuzzy multiobjective model for the supplier selection problem under price breaks in a supply Chain. Int J Prod Econ 121:323-332

Amid A, Ghodsypour SH, O'Brien C (2011) A weighted max-min model for fuzzy multi-objective supplier selection in a supply chain. Int J Prod Econ 131:139-145

Amin SH, Razmi J (2009) An integrated fuzzy model for supplier management: a case study of ISP selection and evaluation. Expert Syst Appl 36(4):8639-8648

Amin SH, Zhang G (2012) An integrated model for closed-loop supply chain configuration and supplier selection: multi-objective approach. Expert Syst Appl 39:6782-6791

Amin SH, Razmi J, Zhang G (2011) Supplier selection and order allocation based on fuzzy SWOT analysis and fuzzy linear programming. Expert Syst Appl 38(1):334-342

Aouadni S, Allouche MA, Rebai A (2013) Supplier selection: an analytic network process and imprecise goal programming model integrating the decision-maker's preferences. Int J Oper Res 16(2):137-154

Aouadni S, Rebai A, Zenonas T (2017) The meaningful mixed data TOPSIS (TOPSIS-MMD) method and its application in supplier selection. Stud Inform Control 26(3):353-363

Araz C, Ozkarahan I (2007) Supplier evaluation and management system for strategic sourcing based on a new multi-criteria sorting procedure. Int J Prod Econ 106:585-606

Arikan F (2013) A fuzzy solution approach for multi objective supplier selection. Expert Syst Appl 40:947-952 
Assadipour G, Razmi J (2012) Possibilistic inventory and supplier selection model for an assembly system. Int J Adv Manuf Technol 67:575-587

Awasthi A, Chauhan SS, Goyal SK, Proth JM (2009) Supplier selection problem for a single manufacturing unit under stochastic demand. Int J Prod Econ 117:229-233

Awasthi A, Chauhan SS, Goyal SK (2010) A fuzzy multicriteria approach for evaluating environmental performance of suppliers. Int J Prod Econ 126(2):370-378

Ayhan MB, Kilic HS (2015) A two stage approach for supplier selection problem in multi-item/multi-supplier environment with quantity discounts. Comput Ind Eng 85(2015):1-12

Bai C, Sarkis J (2010) Integrating sustainability into supplier selection with grey system and rough set methodologies. Int J Prod Econ 124(1):252-264

Barla SB (2003) A case study of supplier selection for lean supply by using a mathematical model. Logist Inf Manag 16(6):451-459

Basnet C, Leung JMY (2005) Inventory lot-sizing with supplier selection. Comput Oper Res 32:1-14

Bayazit O (2006) Use of analytic network process in vendor selection decisions. Benchmarking Int J 13(5):566-579

Beikkhakhian Y, Javanmardi M, Karbasian M, Khayambashi B (2015) The application of ISM model in evaluating agile suppliers selection criteria and ranking suppliers using fuzzy TOPSIS-AHP methods. Expert Syst Appl 42(2015):6224-6236

Bichler M, Schneider S, Guler K, Sayal M (2011) Compact bidding languages and supplier selection for markets with economies of scale and scope. Eur J Oper Res 214:67-77

Boran FE, Genç S, Kurt M, Akay D (2009) A multi-criteria intuitionistic fuzzy group decision making for supplier selection with TOPSIS method. Expert Syst Appl 36(8):11363-11368

Bottani E, Rizzi A (2008) An adapted multi-criteria approach to suppliers and products selection: an application oriented to lead-time reduction. Int J Prod Econ 111(2):763-781

Bruno G, Esposito E, Genovese A, Simpson M (2016) Applying supplier selection methodologies in a multi-stakeholder environment: a case study and a critical assessment. Expert Syst Appl 43(2016):271-285

Burke GJ, Carrillo J, Vakharia AJ (2008) Heuristics for sourcing from multiple suppliers with alternative quantity discounts. Eur J Oper Res 186:317-329

Büyüközkan G, Göçer F (2016) Application of a new combined intuitionistic fuzzy MCDM approach based on axiomatic design methodology for the supplier selection problem. Appl Soft Comp. Available online 1 September 2016, In Press, accepted manuscript - note to users

Büyüközkan G, Göçer F (2017) Application of a new combined intuitionistic fuzzy MCDM approach based on axiomatic design methodology for the supplier selection problem. Appl Soft Comput 52:1222-1238

Cakravastia A, Takahashi K (2004) Integrated model for supplier selection and negotiation in a make-to-order environment. Int J Prod Res 42(21):4457-4474

Cárdenas-Barrón LE, González-Velarde J, Treviño-Garza G (2015) A new approach to solve the multi-product multi-period inventory lot sizing with supplier selection problem. Comput Oper Res 64(2015):225-232

Çebi F, Bayraktar D (2003) An integrated approach for supplier selection. Logist Inf Manag 16(6):395-400

Celebi D, Bayraktar D (2008) An integrated neural network and data envelopment analysis for supplier evaluation under incomplete information. Expert Syst Appl 35(4):1698-1710

Chai JY, Liu JNK, Xu ZS (2012) A new rule-based SIR approach to supplier selection under intuitionistic fuzzy environments. Int $\mathbf{J}$ Uncertain Fuzziness Knowl Based Syst 20(3):451-471
Chai J, James NKL, Eric WTN (2013) Application of decision-making techniques in supplier selection: a systematic review of literature. Expert Syst Appl 40:3872-3885

Chamodrakas I, Batis D, Martakos D (2010) Supplier selection in electronic marketplaces using satisficing and fuzzy AHP. Expert Syst Appl 37(1):490-498

Chan FTS (2003) Interactive selection model for supplier selection process: an analytical hierarchy process approach. Int J Prod Res 41(15):3549-3579

Chan FTS, Chan HK (2010) An AHP model for selection of suppliers in the fast changing fashion market. Int J Adv Manuf Technol 51(9-12):1195-1207

Chan FTS, Kumar N (2007) Global supplier development considering risk factors using fuzzy extended AHP-based approach. OMEGA Int J Manag Sci 35(4):417-431

Chan FTS, Kumar N, Tiwari MK, Lau HCW, Choy KL (2008) Global supplier selection: a fuzzy-AHP approach. Int J Prod Res 46(14):3825-3857

Chang YS, Lee KJ (2010) A comparison shopping optimization model based on suppliers' pricing contexts. Expert Syst Appl 37:5736-5744

Chauhan SS, Proth JM (2003) The concave cost supply problem. Eur J Oper Res 148:374-383

Che ZH (2010) A genetic algorithm-based model for solving multiperiod supplier selection problem with assembly sequence. Int J Prod Res 48(15):4355-4377

Che ZH, Wang HS (2008) Supplier selection and supply quantity allocation of common and non-common parts with multiple criteria under multiple products. Comput Ind Eng 55:110-133

Chen Y-J (2011a) Structured methodology for supplier selection and evaluation in a supply chain. Inf Sci 181(9):1651-1670

Chen T (2011b) Bivariate models of optimism and pessimism in multi-criteria decision-making based on intuitionistic fuzzy sets. Inf Sci 181(11):2139-2165

Chen YH, Chao RJ (2012) Supplier selection using consistent fuzzy preference relations. Expert Syst Appl 39:3233-3240

Chen YM, Huang PN (2007) Bi-negotiation integrated AHP in suppliers selection. Benchmarking Int J 14(5):575-593

Chen LY, Wang T (2009) Optimizing partners' choice in IS/IT outsourcing projects: the strategic decision of fuzzy VIKOR. Int J Prod Econ 120(1):233-242

Chen PS, Wu MT (2013) A modified failure mode and effects analysis method for supplier selection problems in the supply chain risk environment: a case study. Comput Ind Eng 66:634-642

Chen KL, Chen KS, Li RK (2005) Suppliers capability and price analysis chart. Int J Prod Econ 98:315-327

Chen CT, Lin CT, Huang SF (2006) A fuzzy approach for supplier evaluation and selection in supply chain management. Int $\mathrm{J}$ Prod Econ 102(2):289-301

Chen T, Wang H, Lu Y (2011a) A multicriteria group decision-making approach based on interval-valued intuitionistic fuzzy sets: a comparative perspective. Expert Syst Appl 38(6):7647-7658

Chen Y, Wang T, Wu C (2011b) Strategic decisions using the fuzzy PROMETHEE for IS outsourcing. Expert Syst Appl 38(10):13216-13222

Choi TM (2013) Optimal apparel supplier selection with forecast updates under carbon emission taxation scheme. Comput Oper Res 40:2646-2655

Chou SY, Chang YH (2008) A decision support system for supplier selection based on a strategy-aligned fuzzy SMART approach. Expert Syst Appl 34(4):2241-2253

Choudhary D, Shankar R (2013) Joint decision of procurement lotsize, supplier selection, and carrier selection. J Purch Supply Manag 19:16-26 
Choudhary D, Shankar R (2014) A goal programming model for joint decision making of inventory lot-size, supplier selection and carrier selection. Comput Ind Eng 71:1-9

Choy KL, Lee WB (2002) A generic tool for the selection and management of supplier relationships in an outsourced manufacturing environment: the application of case based reasoning. Logist Inf Manag 15(4):235-253

Choy KL, Lee WB (2003) A generic supplier management tool for outsourcing manufacturing. Supply Chain Manag Int $\mathbf{J}$ $8(2): 140-154$

Choy KL, Lee WB, Lo V (2002) Development of a case based intelligent customer-supplier relationship management system. Expert Syst Appl 23(3):281-297

Choy KL, Fan KKH, Lo V (2003) Development of an intelligent customer-supplier relationship management system: the application of case-based reasoning. Ind Manag Data Syst 103(4):263-274

Crama Y, Pascual JR, Torres A (2004) Optimal procurement decisions in the presence of total quantity discounts and alternative product recipes. Eur J Oper Res 159(2):364-378

Dalalah D, Hayajneh M, Batieha F (2011) A fuzzy multi-criteria decision making model for supplier selection. Expert Syst Appl 38(7):8384-8391

De Boer L, Labro E, Morlacchi P (2001) A review of methods supporting supplier Selection. Eur J Purch Supply Manag 7:75-89

Demirtas EA, Üstün O (2008) An integrated multi-objective decision making process for supplier selection and order allocation. Omega 36(1):76-90

Demirtas EA, Üstün O (2009) Analytic network process and multiperiod goal programming integration in purchasing decisions. Comput Ind Eng 56(2):677-690

Deng Y, Chan FTS (2011) A new fuzzy dempster MCDM method and its application in supplier selection. Expert Syst Appl 38(8):9854-9861

Deng S, Aydin R, Kwong CK, Huang Y (2014) Integrated product line design and supplier selection: a multi-objective optimization paradigm. Comput Ind Eng 70:150-158

Denyer D, Tranfield D (2009) Producing a systematic review. In: Buchanan D, Bryman A (eds) Handbook of organizational research methods. Sage Publications, London, pp 671-689

Denyer D, Tranfield D, van Aken JE (2008) Developing design propositions through research synthesis. Organ Stud 29(3):393-413

Dickson GW (1966) An analysis of vendor selection systems and decisions. J Purch 2(1):5-17

Du B, Guo S, Huang X, Li Y, Guo J (2015) A Pareto supplier selection algorithm for minimum the life cycle cost of complex product system. Expert Syst Appl 42(2015):4253-4264

Dulmin R, Mininno V (2003) Supplier selection using a multi-criteria decision aid method. J Purch Supply Manag 9:177-187

Dursun M, Karsak EE (2013) A QFD-based fuzzy MCDM approach for supplier selection. Appl Math Model 37:5864-5875

Dweiri F, Kumar S, Khan SA, Jain V (2016) Designing an integrated AHP based decision support system for supplier selection in automotive industry. Expert Syst Appl 62:273-283

Ebrahim M, Razmi J, Haleh H (2009) Scatter search algorithm for supplier selection and order lot sizing under multiple price discount environment. Adv Eng Softw 40:766-776

Ekici A (2013) An improved model for supplier selection under capacity constraint and multiple criteria. Int J Prod Econ 141:574-581

Esfandiari N, Seifbarghy M (2013) Modeling a stochastic multi-objective supplier quota allocation problem with price-dependent ordering. Appl Math Model 37:5790-5800

Esmaeili AD, Abolfazl K, Behrooz P (2013) A two-level GA to solve an integrated multi-item supplier selection model. Appl Math Comput 219:7600-7615
Faez F, Ghodsypour SH, O’Brien C (2009) Vendor selection and order allocation using an integrated fuzzy case-based reasoning and mathematical programming model. Int J Prod Econ 21:395-408

Falagario M, Sciancalepore F, Costantino N, Pietroforte R (2012) Using a DEA cross efficiency approach in public procurement tenders. Eur J Oper Res 218(2):523-529

Saen RF (2007) Suppliers selection in the presence of both cardinal and ordinal data. Eur J Oper Res 183(2):741-747

Saen RF (2007) A new mathematical approach for supplier selection: accounting for non-homogeneity is important. Appl Math Comput 185(1):84-95

Feng B, Fan Z, Li Y (2011) A decision method for supplier selection in multiservice outsourcing. Int J Prod Econ 132(2):240-250

Garfamy RM (2006) A data envelopment analysis approach based on total cost of ownership for supplier selection. J Enterp Inf Manag 19(6):662-678

Gencer C, Gürpinar D (2007) Analytic network process in supplier selection: a case study in an electronic firm. Appl Math Model 31(11):2475-2486

Ghadikolaei AS, Parkouhi SV (2017) A resilience approach for supplier selection: using fuzzy analytic network process and grey VIKOR techniques. J Clean Prod 161:431-451

Ghaniabadi M, Mazinani A (2017) Dynamic lot sizing with multiple suppliers, backlogging and quantity discounts. Comput Ind Eng 110:67-74

Ghodsypour SH, O`Brien C (2001) The total cost of logistics in supplier selection, under conditions of multiple sourcing, multiple criteria and capacity constraint. Int J Prod Econ 73(1):15-27

Glickman TS, White SC (2008) Optimal vendor selection in a multiproduct supply chain with truckload discounts. Transp Res Part E 44:684-695

Glock CH (2012) Single sourcing versus dual sourcing under conditions of learning. Comput Ind Eng 62:318-328

Golmohammadi D, Mellat-Parast M (2012) Developing a grey-based decision making model for supplier selection. Int J Prod Econ 137(2):191-200

Goossens D, Maas A, Spieksma FCR, van de Klundert J (2007) Exact algorithms for a procurement problem with total quantity discounts. Eur J Oper Res 178(2):603-626

Gorji MH, Setak M, Karimi H (2014) Optimizing inventory decisions in a two-level supply chain with order quantity constraints. Appl Math Model 38(3):814-827

Govindan K, Khodaverdi R, Jafarian A (2013) A fuzzy multi criteria approach for measuring sustainability performance of a supplier based on triple bottom line approach. J Clean Prod 47:345-354

Guneri AF, Yucel A, Ayyildiz G (2009) An integrated fuzzy-lp approach for a supplier selection problem in supply chain management. Expert Syst Appl 36(5):9223-9228

Guneri AF, Ertay T, Yucel A (2011) An approach based on ANFIS input selection and modeling for supplier selection problem. Expert Syst Appl 38(12):14907-14917

Guo C, Li X (2014) A multi-echelon inventory system with supplier selection and order allocation under stochastic demand. Int J Prod Econ 151:37-47

Ha HS, Krishnan R (2008) A hybrid approach to supplier selection for the maintenance of a competitive supply chain. Expert Syst Appl 34(2):1303-1311

Hajji A, Gharbi A, Kenne JP, Pellerin R (2011) Production control and replenishment strategy with multiple suppliers. Eur J Oper Res 208:67-74

Haleh H, Hamidi A (2011) A fuzzy MCDM model for allocating orders to suppliers in a supply chain under uncertainty over a multiperiod time horizon. Expert Syst Appl 38(8):9076-9083

Hammami R, Temponi C, Frein Y (2014) A scenario-based stochastic model for supplier selection in global context with multiple 
buyers, currency fluctuation uncertainties, and price discounts. Eur J Oper Res 233:159-170

Ho W, Xu X, Dey PK (2010) Multi-criteria decision making approaches for supplier evaluation and selection: a literature review. Eur $\mathbf{J}$ Oper Res 202:16-24

Hong GH, Park SC, Jang DS, Rho HM (2005) An effective supplier selection method for constructing a competitive supply-relationship. Expert Syst Appl 28(4):629-639

Hou J, Su D (2007) EJB-MVC oriented supplier selection system for mass customization. J Manuf Technol Manag 18(1):54-71

Hsu B, Chiang C, Shu M (2010) Supplier selection using fuzzy quality data and their applications to touch screen. Expert Syst Appl 37(9):6192-6200

Hsu CH, Wang FK, Tzeng GH (2012) The best vendor selection for conducting the recycled material based on a hybrid MCDM model combining DANP with VIKOR. Resour Conserv Recycl 66:95-111

Huang SH, Keska H (2007) Comprehensive and configurable metrics for supplier selection. Int J Prod Econ 105(2):510-523

Humphreys P, Huang G, Cadden T, McIvor R (2007) Integrating design metrics within the early supplier selection process. J Purch Supply Manag 13:42-52

Igoulalene I, Benyoucef L, Tiwari MK (2015) Novel fuzzy hybrid multi-criteria group decision making approaches for the strategic supplier selection problem. Expert Syst Appl 42(2015):3342-3356

Jadidi O, Zolfaghari SN, Cavalieri S (2014) A new normalized goal programming model for multi-objective problems: a case of supplier selection and order allocation. Int J Prod Econ 148:158-165

Jadidi O, Cavalieri S, Zolfaghari S (2015) An improved multi-choice goal programming approach for supplier selection problems. Appl Math Model 39(2015):4213-4222

Jolai F, Yazdian SA, Shahanaghi K, Khojasteh MA (2011) Integrating fuzzy TOPSIS and multi-period goal programming for purchasing multiple products from multiple suppliers. J Purch Supply Manag 17:42-53

Junior FRL, Osiro L, Carpinetti LCR (2014) A comparison between fuzzy AHP and fuzzy TOPSIS methods to supplier selection. Appl Soft Comput 21:194-209

Kahraman C, Cebeci U, Ulukan Z (2003) Multi-criteria supplier selection using fuzzy AHP. Logist Inf Manag 16(6):382-394

Kang HY, Lee AHI (2010) Inventory replenishment model using fuzzy multiple objective programming: a case study of a high-tech company in Taiwan. Appl Soft Comput 10:1108-1118

Kar AK (2015) A hybrid group decision support system for supplier selection using analytic hierarchy process, fuzzy set theory and neural network. J Comput Sci 6(2015):23-33

Kara SS (2011) Supplier selection with an integrated methodology in unknown environment. Expert Syst Appl 38:2133-2139

Karpak B, Kumcu E, Kasuganti RR (2001) Purchasing materials in the supply chain: Managing a multi-objective task. Eur J Purch Supply Manag 7(3):209-216

Karsak EE, Dursun M (2014) An integrated supplier selection methodology incorporating QFD and DEA with imprecise data. Expert Syst Appl 41(16):6995-7004

Kawtummachai R, Van Hop N (2005) Order allocation in a multiplesupplier environment. Int J Prod Econ 93:231-238

Keskin GA, Ilhan S, Özkan C (2010) The fuzzy ART algorithm: a categorization method for supplier evaluation and selection. Expert Syst Appl 37(2):1235-1240

Khaled AA, Paul SK, Chakraborty RK, Ayuby MS (2011) Selection of suppliers through different multi-criteria decision making techniques. Glob J Manag Bus Res 11(4). ISSN: 0975-5853
Kheljani JG, Ghodsypour SH, O`Brien C (2009) Optimizing whole supply chain benefit versus buyer's benefit through supplier selection. Int J Prod Econ 121:482-493

Kilic HS (2013) An integrated approach for supplier selection in multi-item/multi-supplier environment. Appl Math Model 37:7752-7763

Kokangul A, Susuz Z (2009) Integrated analytical hierarch process and mathematical programming to supplier selection problem with quantity discount. Appl Math Model 33:1417-1429

Krishankumar R, Ravichandran KS, Saeid AB (2017) A new extension to PROMETHEE under intuitionistic fuzzy environment for solving supplier selection problem with linguistic preferences. Appl Soft Comput 60:564-576

Kumar M, Vrat P, Shankar R (2004) A fuzzy goal programming approach for vendor selection problem in a supply chain. Comput Ind Eng 46:69-85

Kumar M, Vrat P, Shankar R (2006) A fuzzy programming approach for vendor selection problem in a supply chain. Int J Prod Econ 101:273-285

Kuo RJ, Hong SY, Huang YC (2010) Integration of particle swarm optimization-based fuzzy neural network and artificial neural network for supplier selection. Appl Math Model 34:3976-3990

Kuo RJ, Pai CM, Lin RH, Chu HC (2015) The integration of association rule mining and artificial immune network for supplier selection and order quantity allocation. Appl Math Comput 250(2015):958-972

Lee AHI (2009) A fuzzy AHP evaluation model for buyer-supplier relationships with the consideration of benefits, opportunities, costs and risks. Int J Prod Res 47(15):4255-4280

Lee CC, Ouyang C (2009) A neural networks approach for forecasting the supplier's bid prices in supplier selection negotiation process. Expert Syst Appl 36(2):2961-2970

Lee AHI, Kang H, Chang C (2009) Fuzzy multiple goal programming applied to TFT-LCD supplier selection by downstream manufacturers. Expert Syst Appl 36(3):6318-6325

Lee AHI, Kang HY, Lai CM, Hong WY (2013) An integrated model for lot sizing with supplier selection and quantity discounts. Appl Math Model 37:4733-4746

Lee J, Cho H, Kim YS (2015) Assessing business impacts of agility criterion and order allocation strategy in multi-criteria supplier selection. Expert Syst Appl 42(2015):1136-1148

Li L, Zabinsky ZB (2011) Incorporating uncertainty into a supplier selection problem. Int J Prod Econ 134:344-356

Li G, Yamaguchi D, Nagai M (2008) A grey-based rough decisionmaking approach to supplier selection. Int J Adv Manuf Technol 36(9-10): 1032-1040

Li S, Murat A, Huang W (2009) Selection of contract suppliers under price and demand uncertainty in a dynamic market. Eur J Oper Res 198:830-847

Liao C, Kao H (2011) An integrated fuzzy TOPSIS and MCGP approach to supplier selection in supply chain management. Expert Syst Appl 38(9):10803-10811

Liao ZY, Rittscher J (2007a) Integration of supplier selection, procurement lot sizing and carrier selection under dynamic demand conditions. Int J Prod Econ 107:502-510

Liao ZY, Rittscher J (2007b) A multi-objective supplier selection model under stochastic demand conditions. Int J Prod Econ 105(1):150-159

Lin RH (2009) An integrated FANP-MOLP for supplier evaluation and order allocation. Appl Math Model 33:2730-2736

Lin RH (2012) An integrated model for supplier selection under a fuzzy situation. Int J Prod Econ 138:55-61

Lin Y, Lin C, Yu H, Tzeng G (2010) A novel hybrid MCDM approach for outsourcing vendor selection: a case study for a semiconductor company in taiwan. Expert Syst Appl 37(7):4796-4804 
Lin CT, Chen CB, Ting YC (2011) An ERP model for supplier selection in electronics industry. Expert Syst Appl 38:1760-1765

Liu FHF, Hai HL (2005) The voting analytic hierarchy process method for selecting supplier. Int J Prod Econ 97(3):308-317

Liu P, Zhang X (2011) Research on the supplier selection of a supply chain based on entropy weight and improved ELECTRE-III method. Int J Prod Res 49(3):637-646

Liu J, Ding FY, Lall V (2000) Using data envelopment analysis to compare suppliers for supplier selection and performance improvement. Supply Chain Manag Int J 5(3):143-150

Liu L, Liang L, JinP X (2006) ATC based coordination of distributed production planning and supplier selection. Appl Math Comput 182:1154-1168

Luo X, Wu C, Rosenberg D, Barnes D (2009) Supplier selection in agile supply chains: an information-processing model and an illustration. J Purch Supply Manag 15:249-262

Mafakheri F, Breton M, Ghoniem A (2011) Supplier selection-order allocation: a two-stage multiple criteria dynamic programming approach. Int J Prod Econ 132(1):52-57

Manerba D, Mansini R (2012) An exact algorithm for the capacitated total quantity discount problem. Eur J Oper Res 222:287-300

Mansini R, Savelsbergh MWP, Tocchella B (2012) The supplier selection problem with quantity discounts and truckload shipping. Omega 40:445-455

Mazdeh MM, Emadikhiav M, Parsa I (2015) A heuristic to solve the dynamic lot sizing problem with supplier selection and quantity discounts. Comput Ind Eng 85(2015):33-43

Meena PL, Sarmah SP, Sarkar A (2011) Sourcing decisions under risks of catastrophic event disruptions. Transp Res Part E 47:1058-1074

Mendoza A, Ventura JA (2010) A serial inventory system with supplier selection and order quantity allocation. Eur J Oper Res 207:1304-1315

Mendoza A, Ventura JA (2012) Analytical models for supplier selection and order quantity allocation. Appl Math Model 36:3826-3835

Moghaddam SK (2015) Fuzzy multi-objective model for supplier selection and order allocation in reverse logistics systems under supply and demand uncertainty. Expert Syst Appl 42(2015):6237-6254

Mohammaditabar D, Ghodsypour SH, Hafezalkotob A (2015) A game theoretic analysis in capacity-constrained supplier-selection and cooperation by considering the total supply chain inventory costs. Int J Prod Econ. Available online 28 November 2015

Montazer GA, Saremi HQ, Ramezani M (2009) Design a new mixed expert decision aiding system using fuzzy ELECTRE III method for vendor selection. Expert Syst Appl 36(8):10837-10847

Muralidharan C, Anantharaman N, Deshmukh SG (2002) A multicriteria group decision-making model for supplier rating. J Supply Chain Manag 38(4):22-33

Narasimhan R, Talluri S, Mendez D (2001) Supplier evaluation and rationalization via data envelopment analysis: an empirical examination. J Supply Chain Manag 37(3):28-37

Narasimhan R, Talluri S, Mahapatra SK (2006) Multiproduct, multicriteria model for supplier selection with product life-cycle considerations. Decis Sci 37(4):577-603

Nazari-Shirkouhi S, Shakouri H, Javadi B, Keramati A (2013) Supplier selection and order allocation problem using a two-phase fuzzy multi-objective linear programming. Appl Math Model 37:9308-9323

Ng WL (2008) An efficient and simple model for multiple criteria supplier selection problem. Eur J Oper Res 186(3):1059-1067

Onüt S, Kara SS, Isik E (2009) Long term supplier selection using a combined fuzzy MCDM approach: a case study for a telecommunication company. Expert Syst Appl 36(2):3887-3895

Osman H, Demirli K (2010) A bilinear goal programming model and a modified Benders decomposition algorithm for supply chain reconfiguration and supplier selection. Int J Prod Econ 124:97-105

Ozgen D, Onuta S, Gulsun B, Tuzkaya RF, Tuzkaya G (2008) A twophase possibilistic linear programming methodology for multiobjective supplier evaluation and order allocation problems. Inf Sci 178(2):485-500

Ozkok BA, Tiryaki F (2011) A compensatory fuzzy approach to multiobjective linear supplier selection problem with multiple-item. Expert Syst Appl 38:11363-11368

Palak G, Ekşioğlu SD, Geunes J (2014) Analyzing the impacts of carbon regulatory mechanisms on supplier and mode selection decisions: an application to a biofuel supply chain. Int J Prod Econ 154:198-216

Pazhani S, Ventura AJ, Mendoza A (2016) A serial inventory system with supplier selection and order quantity allocation considering transportation costs. Appl Math Model 40(2016):612-634

Peng J (2012) Selection of logistics outsourcing service suppliers based on AHP. Energy Procedia 17:595-601

Ravindran AR, Bilsel RU, Wadhwa V, Yang T (2010) Risk adjusted multicriteria supplier selection models with applications. Int J Prod Res 48(2):405-424

Razmi J, Rafiei H (2010) An integrated analytic network process with mixed integer non-linear programming to supplier selection and order allocation. Int J Adv Manuf Technol 49(9-12):1195-1208

Razmi J, Rafiei H, Hashemi M (2009a) Designing a decision support system to evaluate and select suppliers using fuzzy analytic network process. Comput Ind Eng 57(4):1282-1290

Razmi J, Songhori MJ, Khakbaz MH (2009b) An integrated fuzzy group decision making/fuzzy linear programming (FGDMLP) framework for supplier evaluation and order allocation. Int J Adv Manuf Technol 43(5-6):590-607

Rezaei J, Davoodi M (2008) A deterministic, multi-item inventory model with supplier selection and imperfect quality. Appl Math Model 32:2106-2116

Rezaei J, Davoodi M (2011) Multi-objective models for lot-sizing with supplier selection. Int J Prod Econ 130(1):77-86

Rezaei J, Davoodi M (2012) A joint pricing, lot-sizing, and supplier selection model. Int J Prod Res 50(16):4524-4542

Rezaei J, Ortt R (2013) Multi-criteria supplier segmentation using a fuzzy preference relations based AHP. Eur J Oper Res 225(2013):75-84

Rezaei J, Fahim PBM, Tavasszy L (2014) Supplier selection in the airline retail industry using a funnel methodology: conjunctive screening method and fuzzy AHP. Expert Syst Appl 41(2014):8165-8179

Rezaei J, Davoodi M, Tavasszy L, Davarynejad M (2015a) A multiobjective model for lot-sizing with supplier selection for an assembly system. Int J Logist Res Appl 19(2):125-142

Rezaei J, Wang J, Tavasszy L (2015b) Linking supplier development to supplier segmentation using best worst method. Expert Syst Appl 42(2015):9152-9164

Rezaei J, Nispeling T, Sarkis J, Tavasszy L (2016) A supplier selection life cycle approach integrating traditional and environmental criteria using the best worst method. J Clean Prod 135:577-588

Roshandel J, Miri-Nargesi SS, Hatami-Shirkouhi L (2013) Evaluating and selecting the supplier in detergent production industry using hierarchical fuzzy TOPSIS. Appl Math Model 37:10170-10181

Rouyendegh BD, Saputro TE (2014) Supplier selection using integrated fuzzy TOPSIS and MCGP: a case study. Procedia Soc Behav Sci 116:3957-3970

Ruiz-Torres AJ, Mahmoodi F, Amy ZZ (2013) Supplier selection model with contingency planning for supplier failures. Comput Ind Eng 66:374-382

Sadeghieh A, Dehghanbaghi M, Dabbaghi A, Barak S (2012) A genetic algorithm based grey goal programming (G3) approach 
for parts supplier evaluation and selection. Int J Prod Res 50(16):4612-4630

Saen RF (2006) A decision model for selecting technology suppliers in the presence of nondiscretionary factors. Appl Math Comput 181(2):1609-1615

Sanayei A, Mousavi SF, Abdi MR, Mohaghar A (2008) An integrated group decision making process for supplier selection and order allocation using multi-attribute utility theory and linear programming. J Frankl Inst 345:731-747

Sanayei A, Farid MS, Yazdankhah A (2010) Group decision making process for supplier selection with VIKOR under fuzzy environment. Expert Syst Appl 37(1):24-30

Sarkis J, Talluri S (2002) A model for strategic supplier selection. J Supply Chain Manag 38(4):18-28

Sawik T (2010) Single vs.multiple objective supplier selection in a make to order environment. Omega 38:203-212

Sawik T (2011a) Selection of a dynamic supply portfolio in maketo-order environment with risks. Comput Oper Res 38:782-796

Sawik T (2011b) Selection of supply portfolio under disruption risks. Omega 39:194-208

Sawik T (2011c) Supplier selection in make-to-order environment with risks. Math Comput Model 53(9-10):1670-1679

Sawik T (2013) Selection of resilient supply portfolio under disruption risks. Omega 41:259-269

Sawik T (2014) Joint supplier selection and scheduling of customer orders under disruption risks: single vs. dual sourcing. Omega 43:83-95

Scott J, Ho W, Dey PK, Talluri S (2015) A decision support system for supplier selection and order allocation in stochastic, multistakeholder and multi-criteria environments. Int J Prod Econ 166(2015):226-237

Segura M, Maroto C (2017) A multiple criteria supplier segmentation using outranking and value function methods. Expert Syst Appl 69:87-100

Sen CG, Sen S, Baslgil H (2010) Pre-selection of suppliers through an integrated fuzzy analytic hierarchy process and max-min methodology. Int J Prod Res 48(6):1603-1625

Senyigit E, Soylemez I (2012) The analysis of heuristics for lot sizing with supplier selection problem. WC-BEM 2012. Procedia Soc Behav Sci 62:672-676

Sevkli M (2010) An application of the fuzzy ELECTRE method for supplier selection. Int J Prod Res 48(12):3393-3405

Sevkli M, Koh SCL, Zaim S, Demirbag M, Tatoglu E (2007) An application of data envelopment analytic hierarchy process for supplier selection: a case study of BEKO in Turkey. Int J Prod Res 45(9):1973-2003

Seydel J (2005) Supporting the paradigm shift in vendor selection: multicriteria methods for sole-sourcing. Manag Finance 31(3):49-66

Seydel J (2006) Data envelopment analysis for decision support. Ind Manag Data Syst 106(1):81-95

Shaw K, Shanka R, Surendra SY, Lakshman ST (2012) Supplier selection using fuzzy AHP and fuzzy multi-objective linear programming for developing low carbon supply chain. Expert Syst Appl 39:8182-8192

Shemshadi A, Shirazi H, Toreihi M, Tarokh MJ (2011) A fuzzy VIKOR method for supplier selection based on entropy measure for objective weighting. Expert Syst Appl 38(10):12160-12167

Shen C, Yu K (2009) Enhancing the efficacy of supplier selection decision-making on the initial stage of new product development: a hybrid fuzzy approach considering the strategic and operational factors simultaneously. Expert Syst Appl 36(2009):11271-11281

Shi J, Zhang G, Sha J (2011) Jointly pricing and ordering for a multiproduct multi-constraint newsvendor problem with supplier quantity discounts. Appl Math Model 35:3001-3011
Shirinfar M, Haleh H (2011) Supplier selection and evaluation by fuzzy multi-criteria decision making methodology. Int J Ind Eng Prod Res 22(4):271-280

Shyur HJ, Shih HS (2006) A hybrid MCDM model for strategic vendor selection. Math Comput Model 44:749-761

Simić D, Svirčević V, Simić S (2015) A hybrid evolutionary model for supplier assessment and selection in inbound logistics. J Appl Log 13(2015):138-147

Singh A (2014) Supplier evaluation and demand allocation among suppliers in a supply chain. J Purch Supply Manag 20(2014):167-176

Sodenkamp MA, Tavana M, Caprio DD (2016) Modeling synergies in multi-criteria supplier selection and order allocation: an application to commodity trading. Eur J Oper Res 254(3):859-874

Songhori MJ, Tavana M, Azadeh A, Khakbaz MH (2011) A supplier selection and order allocation model with multiple transportation alternatives. Int J Adv Manuf Technol 52(1-4):365-376

Soto AV, Chowdhury NT, Allahyari MZ, Azab A, Baki MF (2017) Mathematical modeling and hybridized evolutionary LP local search method for lot-sizing with supplier selection, inventory shortage, and quantity discounts. Comput Ind Eng 109:96-112

Talluri S (2002) A buyer-seller game model for selection and negotiation of purchasing bids. Eur J Oper Res 143(1):171-180

Talluri S, Baker RC (2002) A multi-phase mathematical programming approach for effective supply chain design. Eur J Oper Res 41(3):544-558

Talluri S, Narasimhan R (2003) Vendor evaluation with performance variability: a max-min approach. Eur J Oper Res 146(3):543-552

Talluri S, Narasimhan R (2004) A methodology for strategic sourcing. Eur J Oper Res 154(1):236-250

Talluri S, Narasimhan R, Nair A (2006) Vendor performance with supply risk: a chance-constrained DEA approach. Int J Prod Econ 100(2):212-222

Tam MCY, Tummala VMR (2001) An application of the AHP in vendor selection of a telecommunications system. Omega Int J Manag Sci 29(2):171-182

Tavana M, Fallahpour A, Caprio DD, Santos-Arteaga FJ (2016) A hybrid intelligent fuzzy predictive model with simulation for supplier evaluation and selection. Expert Syst Appl 61:129-144

Torabi SA, Baghersad M, Mansouri SA (2015) Resilient supplier selection and order allocation under operational and disruption risks. Transp Res Part E 79(2015):22-48

Tsai YL, Yang YJ, Lin CH (2010) A dynamic decision approach for supplier selection using ant colony system. Expert Syst Appl 37(12):8313-8321

Tseng M, Chiang JH, Lan LW (2009) Selection of optimal supplier in supply chain management strategy with analytic network process and choquet integral. Comput Ind Eng 57(1):330-340

Turk S, Zcan EO, John R (2017) Multi-objective optimisation in inventory planning with supplier selection. Expert Syst Appl 78:51-63

Ustun O, Demirtas E (2008) Multi-period lot-sizing with supplier selection using achievement scalarizing functions. Comput Ind Eng 54:918-931

Ventura JA, Valdebenito VA, Golany B (2013) A dynamic inventory model with supplier selection in a serial supply chain structure. Eur J Oper Res 230:258-271

Wadhwa V, Ravindran AR (2007) Vendor selection in outsourcing. Comput Oper Res 34(12):3725-3737

Wan S, Xu G, Dong J (2017) Supplier selection using ANP and ELECTRE II in interval 2-tuple linguistic environment. Inf Sci 385-386:19-38

Wang HS (2008) Configuration change assessment: genetic optimization approach with fuzzy multiple criteria for part supplier selection decisions. Expert Syst Appl 34(2):1541-1555 
Wang HS, Che ZH (2007) An integrated model for supplier selection decisions in configuration changes. Expert Syst Appl 32:1132-1140

Wang T, Yang Y (2009) A fuzzy model for supplier selection in quantity discount environments. Expert Syst Appl 36(10):12179-12187

Wang G, Huang SH, Dismukes JP (2004) Product-driven supply chain selection using integrated multi-criteria decision-making methodology. Int J Prod Econ 91(1):1-15

Wang G, Huang SH, Dismukes JP (2005) Manufacturing supply chain design and evaluation. Int J Adv Manuf Technol 25(1-2):93-100

Ware NR, Singh SP, Banwet DK (2014) A mixed-integer non-linear program to model dynamic supplier selection problem. Expert Syst Appl 41:671-678

Wetzstein A, Hartmann E, Benton WC, Hohenstein N (2016) A systematic assessment of supplier selection literature-state-of-the- art and future scope. Int J Prod Econ 182:304-323

Woo HS, Saghiri S (2011) Order assignment considering buyer, third-party logistics provider, and suppliers. Int J Prod Econ 130:144-152

Wood DA (2016) Supplier selection for development of petroleum industry facilities, applying multi-criteria decision making techniques including fuzzy and intuitionistic fuzzy TOPSIS with flexible entropy weighting. J Nat Gas Sci Eng 28:594-612

Wu D (2009a) Supplier selection: a hybrid model using DEA, decision tree and neural network. Expert Syst Appl 36(5):9105-9112

Wu D (2009b) Supplier selection in a fuzzy group setting: a method using grey related analysis and Dempster-Shafer theory. Expert Syst Appl 36(5):8892-8899

Wu T, Blackhurst J (2009) Supplier evaluation and selection: an augmented DEA approach. Int J Prod Res 47(16):4593-4608

Wu T, Shunk D, Blackhurst J, Appalla R (2007) AIDEA: a methodology for supplier evaluation and selection in a supplier-based manufacturing environment. Int $\mathbf{J}$ Manuf Technol Manag 11(2):174-192

Wu DD, Zhang Y, Wu D, Olson DL (2010) Fuzzy multi-objective programming for supplier selection and risk modeling: a possibility approach. Eur J Oper Res 200(3):774-787

Wu Y, Chen K, Zeng B, Xu H, Yang Y (2016) Supplier selection in nuclear power industry with extended VIKOR method under linguistic information. Appl Soft Comput 48:444-457

Xia W, Wu Z (2007) Supplier selection with multiple criteria in volume discount environments. OMEGA Int J Manag Sci 35(5):494-504

Xiao Z, Chen W, Li L (2012) An integrated FCM and fuzzy soft set for supplier selection problem based on risk evaluation. Appl Math Model 36:1444-1454

Xu J, Ding C (2011) A class of chance constrained multiobjective linear programming with birandom coefficients and its application to vendors selection. Int J Prod Econ 131:709-720

$\mathrm{Xu}$ N, Nozick L (2009) Modeling supplier selection and the use of option contracts for global supply chain design. Comput Oper Res 36(10):2786-2800
Xu J, Yan F (2011) A multi-objective decision making model for the vendor selection problem in a bifuzzy environment. Expert Syst Appl 38:9684-9695

Yang CC, Chen BS (2006) Supplier selection using combined analytical hierarchy process and grey relational analysis. J Manuf Technol Manag 17(7):926-941

Yang JL, Chiu HN, Tzeng GH, Yeh RH (2008) Vendor selection by integrated fuzzy MCDM techniques with independent and interdependent relationships. Inf Sci 178(21):4166-4183

Yang PC, Wee HM, Pai S, Tseng YF (2011) Solving a stochastic demand multi-product supplier selection model with service level and budget constraints using genetic algorithm. Expert Syst Appl 38(12):14773-14777

You XY, You JX, Liu HCh, Zhen L (2015) Group multi-criteria supplier selection using an extended VIKOR method with interval 2-tuple linguistic information. Expert Syst Appl 42(2015):1906-1916

Yu JR, Tsai C (2008) A decision framework for supplier rating and purchase allocation: a case in the semiconductor industry. Comput Ind Eng 5:634-646

Yu Ch, Wong TN (2015) An agent-based negotiation model for supplier selection of multiple products with synergy effect. Expert Syst Appl 42(2015):223-237

Yu MC, Goh M, Lin HC (2012) Fuzzy multi-objective vendor selection under lean procurement. Eur J Oper Res 219(2):305-311

Yucel A, Guneri AF (2011) A weighted additive fuzzy programming approach for multi-criteria supplier selection. Expert Syst Appl 38:6281-6286

Yücel E, Karaesmen F, Salman FS, Türkay M (2009) Optimizing product assortment under customer-driven demand substitution. Eur J Oper Res 199:759-768

Yucenur GN, Vayvay Ö, Demirel NÇ (2011) Supplier selection problem in global supply chains by AHP and ANP approaches under fuzzy environment. Int J Adv Manuf Technol 56(5-8):823-833

Zeydan M, Çolpan C, Çobanoglu C (2011) A combined methodology for supplier selection and performance evaluation. Expert Syst Appl 38(3):2741-2751

Zhang G (2010) The multi-product newsboy problem with supplier quantity discounts and a budget constraint. Eur J Oper Res 206:350-360

Zhang JL, Zhang MY (2011) Supplier selection and purchase problem with fixed cost and constrained order quantities under stochastic demand. Int J Prod Econ 129:1-7

Zhong L, Yao L (2017) An ELECTRE I-based multicriteria group decision making method with interval type-2 fuzzy numbers and its application to supplier selection. Appl Soft Comput J 57:556-576 